\title{
What's SEX Got TO Do With IT: QUESTIONING RESEARCH ON GENDER \& NEGOTIATION
}

\author{
Andrea Kupfer Schneider*
}

\section{TABLE OF CONTENTS}

INTRODUCTION

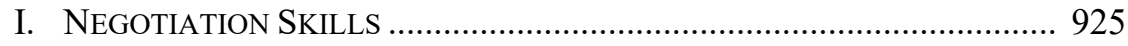

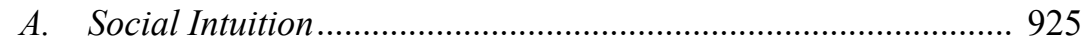

1. Why This Skill Matters in Negotiation ................................. 926

2. Differences That Are Found.............................................. 929

3. Future Research Directions ............................................... 932

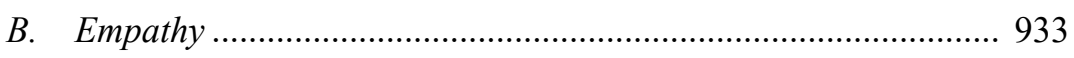

1. Why This Skill Matters in Negotiation ................................ 934

2. Differences That Are Found............................................... 935

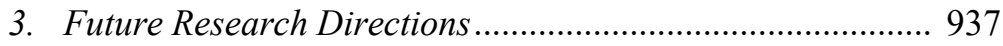

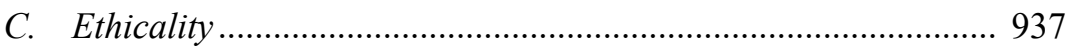

1. Why This Skill Matters in Negotiation ................................. 938

2. Differences That Are Found................................................ 939

3. Future Research Directions ................................................ 942

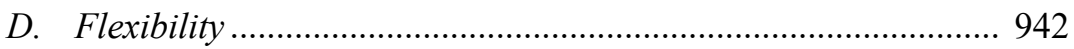

1. Why This Skill Matters in Negotiation ............................... 942

2. Differences That Are Found.................................................. 943

3. Future Research Directions.................................................. 945

E. Assertiveness .......................................................................... 945

1. Why This Skill Matters in Negotiation ................................. 945

2. Differences That Have Been Found .................................... 947

* Professor of Law and Director of the Dispute Resolution Program, Marquette University Law School. I am grateful to the ASU WIP attendees, faculty at the University of Wisconsin-Madison Law School, the School of Public Environmental Affairs at University of Indiana-Bloomington, the Program on Negotiation, at Harvard Law School and UNLV William S. Boyd School of Law for their very helpful feedback. Thanks to participants at the Park City Writers Workshop for their suggestions in outlining and organizing this. And much appreciation to Cynthia Alkon, Art Hinshaw, Michael Moffitt, Jean Sternlight and Nancy Welsh for excellent suggestions. Last, but not least, many thanks to my wonderful research assistants Taylor Chase, April Kutz, Dominic Rosso, and William Ruffing. 
"I would rather trust a woman's instinct than a man's reason."-Stanley Baldwin, Former British Prime Minister ${ }^{1}$

\section{INTRODUCTION}

Negotiation scholars and teachers often talk about negotiation skills through the metaphor of tools in the toolbox. Teachers want to make sure that students have a variety of tools and we push our students to recognize the importance of each, even quoting the old cliché that "[i]f the only tool you have is a hammer, it is tempting to treat everything as if it were a nail."2

This article focuses on the fact that negotiation scholarship primarily studies the hammer, the skill of assertiveness in negotiation. In fact, the majority of empirical negotiation studies take this even further-studying only the hammer and imagining only a single opportunity to hit the nail on the head. Based on those studies, we make conclusions that if one chooses not to use the hammer at all or does not hold it as well as another, one is not a good builder. And negotiation scholars' advice is also too often focused only on this hammer-how to swing it harder, how to position your hands, the angle of the swing, and so forth. If we were teaching a class on building a home, we would recognize the need to ensure our construction crew had skills with other tools as well. Yet, the studies of negotiation skills fail to acknowledge this fact.

This gap is particularly notable when examining gender and negotiation. The vast majority of articles examining gender and negotiation focus on assertiveness - the hammer - and how women need to pick it up, swing harder, or hold it differently. ${ }^{3}$ Women's supposed lack of assertiveness has been used to

1 Stacy M. Roberts, Gendered Differences in Negotiation: Advancing an Understanding of Sources, Effects, and Awareness, 18 CARDOZO J. CONFLICT Resol. 71, 71 (2016).

2 Arthur G. Wirth, Foreward to Abraham H. Maslow, The Psychology of Science: A RECONNAISSANCE, at $\mathrm{x}$ (1966).

3 See Linda Babcock \& Sara Laschever, Women Don't Ask: Negotiation and the Gender Divide 3 (2003); Linda Babcock et al., Nice Girls Don't Ask, Harv. Bus. Rev., Oct. 2003, at 14; Jessica A. Kennedy \& Laura J. Kray, A Pawn in Someone Else's Game?: The Cognitive, Motivational, and Paradigmatic Barriers to Women's Excelling in Negotiation, 35 Res. Organizational Behav. 3, 3-4 (2015); Dina W. Pradel et al., When Does Gender Matter in Negotiation?, Negot. (Harv. Bus. Sch., Cambridge, Mass.), Nov. 2005, at 3; Roberts, supra note 1, at 83-84; Leigh Thompson, Research: Simple Prompts Can Get Women to Negotiate More Like Men, and Vice Versa, HARv. Bus. Rev. (Sept. 17, 2018), https://hbr.org/2018/09/research-simple-prompts-can-get-women-to-negotiate-more-like-me n-and-vice-versa [https://perma.cc/TV9W-3MUG]. But see Amy Cohen, Note, Gender: An (Un)Useful Category of Prescriptive Negotiation Analysis?, 13 TEX. J. WOMEN \& L. 169, 173 (2003); see also Daniel Del Gobbo, The Feminist Negotiator's Dilemma, 33 Онго Sт. J. DisP. RESOL. 1 (2018) (arguing for a more fluid and nuanced view of women and negotiation). 
explain the pay gap between the salaries of women and men along with a whole host of other inequities. ${ }^{4}$ This story falls short primarily because our research falls short. And when our research falls short-when we are only researching and emphasizing a part of the skills that are needed to be effective- this does a disservice to all negotiators.

In some of the most high profile and high stress negotiations, the recognition that more than assertiveness is needed was a hard won lesson. Since the 1990s, both the FBI and NYPD hostage negotiation teams' training reflect that understanding that even alpha personalities in typically alpha jobs need to expand their negotiation toolbox. ${ }^{5}$ Their intensive negotiation trainings focus on how to read others, build rapport, and how to listen to others. ${ }^{6}$ The need to learn more than assertiveness, of course, permeates most negotiation textbooks and popular advice books as well. Yet our empirical research - particularly on these other skills in negotiation-is lacking.

First, researchers focus on assertiveness, a typically masculine trait, and only one of several important negotiation skills. Therefore, we assume that both men and women need only to master that skill to the detriment of the mastery of any other negotiation skills. Second, assertiveness has become the only regularly tested negotiation skill as it is easily quantified. By failing to study the impact of any other skills - including skills that women might be better at than men - the practice to theory to practice cycle is hijacked by this narrow focus. Third, we tend to study negotiation in one-shot interactions with distributive outcomes. Far less often do we study the possibility of integrative outcomes. Even when we set up studies that focus on repeated interactions, they are often

4 See Jae Yun Kim et al., Lean In Messages Increase Attributions of Women's Responsibility for Gender Inequality, 115 J. PersonAlity \& Soc. Psychol. 974, 976 (2018); Michelle A. Travis, Disabling the Gender Pay Gap: Lessons from the Social Model of Disability, 91 DenV. U. L. ReV. 893, 898 (2014). But see Amy J. Schmitz, Sex Matters: Considering Gender in Consumer Contracting, 19 CARDOZO J.L. \& GENDER 437, 483 (2013) (arguing that contract structures and interpretation disadvantage women); see generally Melissa J. Williams et al., The Masculinity of Money: Automatic Stereotypes Predict Gender Differences in Estimated Salaries, 34 Psychol. Women Q. 7 (2010) (finding that stereotypes of male and wealth, rather than women's skills, make the difference in salary).

5 See, e.g., Chris Voss, Never Split the Difference: Negotiating as If Your Life DEPENDED ON IT 13-15 (2016) (explaining how FBI hostage negotiation training shifted to focus on empathy and listening in the 1990s); Jeff Thompson, Active Listening Techniques of Hostage and Crisis Negotiators, PsychOL. TODAY (Nov. 5, 2013), https://www.psychologyt oday.com/us/blog/beyond-words/201311/active-listening-techniques-hostage-crisis-negotiat ors [https://perma.cc/M252-7SQG].

6 See The Negotiator's Fieldbook: The Desk Reference for the Experienced Negotiator app. at 726 (Andrea Kupfer Schneider \& Chris Honeyman eds., 2006); Maria Volpe et al., Negotiating with the Unknown, in 2 The Negotiator's DesK ReferenCE 297, 297 (Chris Honeyman \& Andrea Kupfer Schneider eds., 2017); Jeff Thompson, Hostage \& Crisis Negotiators: Nonverbal Communication Basics, Psychol. TodAy (Aug. 13, 2013), https://www.psychologytoday.com/us/blog/beyond-words/201308/hostage-crisis-negotiators -nonverbal-communication-basics?amp= [https://perma.cc/PE5M-2ETG]. 
limited to prisoner's dilemma or dictator game scenarios - highly stylized and unrealistic structures. ${ }^{7}$ What this means is that while women are not recognized for the skills at which they might be inherently better, it also means that we are failing men by not highlighting opportunities for growth and improvement.

This article attempts to fill in the picture of the skills necessary for effective negotiation by examining the existing negotiation and gender literature discussing traits and skills related to negotiation and the gender literature of those traits outside of the negotiation context. Importantly, this article outlines what we know - and what is still missing - in terms of research on negotiation skills and research on gender differences in these skills. Understanding this gap is the first step toward recognizing what we should be studying and testing in the future.

Any article which discusses male and female traits in negotiation is likely getting it wrong, at least as it applies to some part of the population. ${ }^{8}$ The studies cited throughout this article refer only to men and women (or boys and girls) with little distinction of whether that was the gender at birth, with little understanding of gender fluidity, or with little attention to how each person might take on masculine or feminine traits. ${ }^{9}$

In addition, as we study gender differences in negotiation, this article does not pretend to make conclusions about whether these behaviors are biological or socialized - nature or nurture. ${ }^{10}$ Some of the studies cited do focus on that issue - and in those cases, a parenthetical will note that when citing the study. Most of the studies, however, report on behaviors exhibited by negotiators without claiming that this behavior is inherently biological or one stemming from socialization. ${ }^{11}$

7 See, e.g., Amy R. Bland et al., Cooperative Behavior in the Ultimatum Game and Prisoner's Dilemma Depends on Players' Contributions, 3 Frontiers Psychol. 1 (June 2017), htt ps://www.frontiersin.org/articles/10.3389/fpsyg.2017.01017/full [https://perma.cc/E22F-8L9 $\mathrm{X}]$.

8 These labels should probably be masculine or feminine rather than a binary biological identity recognizing that anyone is capable of behavior along a range. And a binary label itself is overly simplistic as gender identity continues to shift. Kerry Manders, Beyond the Narrow Expectations of Gender, N.Y. TIMES (Oct. 16, 2018), https://www.nytimes.com/201 8/10/16/lens/beyond-the-narrow-expectations-of-gender.html [https://perma.cc/68GW-2P7 4].

9 There is even less thought to how sexual preferences might in fact impact which traits are utilized by any individual negotiator. But see, e.g., Daniel Nettle, Empathizing and Systemizing: What Are They, and What Do They Contribute to Our Understanding of Psychological Sex Differences?, 98 BRITISH J. Psychol. 237 (2007) (providing an example of a study examining differences in sexual identity as well as biology).

10 But see Diane F. Halpern \& Mary L. LaMay, The Smarter Sex: A Critical Review of Sex Differences in Intelligence, 12 EDUC. PSYCHOL. REV. 229 (2000) (explaining biological versus socialized differences).

11 But see generally Leonardo Christov-Moore et al., Empathy: Gender Effects in Brain and Behavior, 46 NEUROSCIENCE \& BiobeHAVIORAL REV. 604 (2014) (examining both biological and socialized differences in empathy). 
Finally, the studies this article discusses are, by and large, studies of US and Western men and women and often conducted on adolescent or collegeaged adults. ${ }^{12}$ One must assume that studies of other populations, other ethnicities, and other ages might reveal other differences. ${ }^{13}$

We can imagine that other factors could determine negotiation behavior more than gender - birth order, where one lives now, where one was raised, family or cultural expectations, professional training, political leanings, ${ }^{14}$ level of experience, and so on. Yet these other factors are rarely studied in detail the way that gender has been over the last 40 years. Why is there such a focus on negotiation differences between women and men? Perhaps we study this because gender differences are the most salient to us (think of how popular gender reveal parties have become!); perhaps it is because changing gender roles are so important to us; perhaps it is because gender is the easiest to sort; perhaps it is because it is the difference that fascinates us the most. In any case, we actually do not know if other, unstudied, factors would have far more impact among negotiators.

Furthermore, in any study of behavioral differences, people fall along a bell curve of behavior. Perhaps, for example, some negotiators from Asian cultures would view direct eye contact toward a superior as troubling but many others - along the sides of the bell curve-would not. ${ }^{15}$ And we never know in

12 See generally Joseph Henrich et al., The Weirdest People in the World?, 33 BeHAV. \& BRAIN SCI. 61, 61 (2010) (noting that "[b]ehavioral scientists routinely publish broad claims about human psychology and behavior in the world's top journals based on samples drawn entirely from Western, Educated, Industrialized, Rich, and Democratic (WEIRD) societies. Researchers - often implicitly - assume that either there is little variation across human populations, or that these 'standard subjects' are as representative of the species as any other population" and "that members of WEIRD societies, including young children, are among the least representative populations one could find for generalizing about humans."); Erik C. Nook et al., The Nonlinear Development of Emotion Differentiation: Granular Emotional Experience Is Low in Adolescence, 29 PsyCHOL. SCI. 1346, 1347 (2018) (studying 199 participants between the ages of four and twenty-five years old).

13 And this does not even begin to address the issue of intersectionality where race, gender, and other identifying differences could all impact behavior. See, e.g., Ronald F. Levant \& Wizdom A. Powell, The Gender Role Strain Paradigm, in The Psychology of Men AND MASCULINITIES 15, 28 (Ronald F. Levant \& Y. Joel Wong eds., 2017) (discussing the gender role strain paradigm and how race, social position, and sexual orientation all intersect with gender roles); see generally Negin R. Toosi et al., Who Can Lean in? The Intersecting Role of Race and Gender in Negotiations, 43 Psychol. Women Q. 17, 17 (2019); Wu Liu \& Leigh Anne Liu, Cultural Intelligence in International Business Negotiation 3 (May 2006) (unpublished theoretical paper), https://papers.ssrn.com/sol3/papers.cfm?abstract_id=905460 [https://perma.cc/Z3LN-XYKT].

14 See John R. Hibbing et al., Predisposed: Liberals, Conservatives, and the Biology of Political Differences 6 (2014) (arguing that even our political perspectives could be determined, in part, by biology).

15 See, e.g., Hironori Akechi et al., Attention to Eye Contact in the West and East: Autonomic Responses and Evaluative Ratings, 8 PLOS ONE 1, 1 (2013); Thomas Rockstuhl \& Linn Van Dyne, A Bi-Factor Theory of the Four-Factor Model of Cultural Intelligence: Meta- 
advance whether our counterpart falls in the middle or on the ends of the bell curve. Frankly, we often do not even know that about ourselves. ${ }^{16}$ So it is important to recognize that the negotiation studies discussed herein and the generalities that come from them might, or might not, apply to any given negotiator. They are conclusions drawn from generalizations about negotiators who fall in the middle of that bell curve of behavior, whatever the particular behavior is that is being measured.

Moreover, some of the studies often cited for examples of gender difference are more than 40 years old. ${ }^{17}$ That should give us pause about assuming that any or all of these conclusions still apply. These historic studies are noted, and the reader is encouraged to be aware of when and how these studies were conducted..$^{18}$ One should question if certain assumptions might have changed about male and female behavior since these studies were conducted. ${ }^{19}$

This article will examine five negotiation skills - social intuition, empathy, ethicality, flexibility, and assertiveness - each of which has been shown to make negotiators more effective and add importantly to each negotiator's toolbox. Each section will outline how the skill is generally defined in negotiation literature, what gender differences or research has been done under each category, and then where future research might be needed. Particularly, this article will note how much more research is needed in all of these other skills to help negotiators learn the specific behaviors that can increase effectiveness. Back to our toolbox analogy, it would be helpful to have studies on what type of wrench is most useful or how to best turn a screwdriver, in addition to the numerous studies done on hammering. In each of these sections when I review differences that have been found in studies, there is clearly the caveat that these differences are only what has been found or what has been studied and that, as with all studies, the article is limited by the limitations of the studies themselves. Finally, the article will circle back to assess what we have learned about using a gender lens to study negotiation and the importance of broadening the skill base for all negotiators.

Analysis and Theoretical Extensions, 148 Organizational Behav. \& Hum. Decisions PROCESSES 124, 124 (2018) (studying the impact of cultural intelligence). See generally Jeswald W. Salacuse, Ten Ways That Culture Affects Negotiating Style: Some Survey Results, 14 NeGOT. J. 221, 221 (1998).

${ }^{16}$ It is, in fact, why I started studying gender and negotiation since I found that many of the supposed truths about female negotiators seemed exactly opposite of what I did or was expected to do.

17 See, e.g., Max Gluckman, Gossip and Scandal, 4 CURrent Anthropology 307, 307, 315 (1963).

18 Many footnotes will have parentheticals explaining the methodology of the studies.

19 See, e.g., Edward H. Thompson, Jr. \& Kate M. Bennett, Masculinity Ideologies, in THE Psychology of Men and Masculinities 45, 52 (Ronald F. Levant \& Y. Joel Wong eds., 2017); Laura J. Kray \& Michael P. Haselhuhn, Multifaceted Masculinity: Implications for Men's Lives, 62 PsycCRITIQUES 417 (2017) (reviewing The Psychology of Men AND MASCULINITIES (Ronald F. Levant \& Y. Joel Wong eds., 2017)). 


\section{NegOtIATION SKILLS}

Negotiation theory now acknowledges at least five different skills that can be tied to effective negotiation behavior. Stemming from early writing on the tension between claiming value and creating value,${ }^{20}$ as well as the psychological literature that outlines five basic conflict tendencies of competing, compromising, collaborating, avoiding, and accommodating - along two axes of concern with self and concern with others, ${ }^{21}$ the skills of assertiveness and empathy have been taught in the literature for years. ${ }^{22}$ Similarly, the skill of creativity as it is needed to be able to create value, has received much attention. ${ }^{23}$ Separately, writing about trust and reputation in negotiation consistently argues that effective negotiators create and guard their reputation carefully. ${ }^{24}$ Finally, and perhaps most recently, the research into emotional intelligence and nonverbal communication skills, has been coalesced into the umbrella of social intuition. ${ }^{25}$ We now turn to each of these.

\section{A. Social Intuition}

Negotiation often depends on the relationship between the negotiators. How they communicate over the content of the negotiation can impact the building of rapport and trust. ${ }^{26}$ The exchange of information in a negotiation on the content level is, of course, crucial to finding a settlement. Yet other aspects of the information exchange are related to the emotion, mood, ${ }^{27}$ and tone of the

20 See David A. Lax \& James K. Sebenius, The Manager as Negotiator: Bargaining FOR COOPERATION AND COMPETITIVE GAIN 29 (1986).

21 See Kenneth Thomas, Conflict and Conflict Management, in 1 HaNDBOOK OF INDUSTRIAL and Organizational Psychology 900-02 (Marvin D. Dunnette ed., 1976).

22 See generally Robert H. Mnookin et al., The Tension Between Empathy and Assertiveness, 12 NeGOT. J. 217 (1996).

23 See sources cited infra note 148 and accompanying text.

${ }^{24}$ See discussion infra Section I.C.

25 See infra notes 27-30 and accompanying text.

26 See Roy J. Lewicki, Trust and Distrust, in 1 The Negotiator's Desk Reference 201, 202 (Chris Honeyman \& Andrea Kupfer Schneider eds., 2017); Roy J. Lewicki, Repairing Trust, in 1 The Negotiator's Desk ReferenCE, supra, at 218; Roy J. Lewicki \& Edward C. Tomlinson, Trust, Trust Development, and Trust Repair, in The HANDBOOK OF Conflict Resolution: Theory and Practice 104 (Peter T. Coleman et al. eds., 3d ed. 2014);

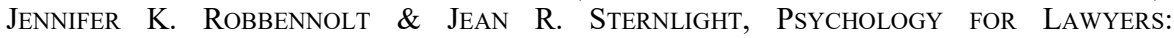
Understanding the Human Factors in Negotiation, Litigation, and Decision Making 260 (2012); Michael Morris et al., Schmooze or Lose: Social Friction and Lubrication in EMail Negotiations, 6 Group DynAmiCs: TheORY, ReS., \& PRAC. 89, 90 (2002); see generally Janice Nadler, Rapport in Negotiation and Conflict Resolution, 87 MARQ. L. REv. 875 (2004).

27 See Clark Freshman, Yes, and: Core Concerns, Internal Mindfulness, and External Mindfulness for Emotional Balance, Lie Detection, and Successful Negotiation, 10 NEv. L.J. 365, 383 (2010); Clark Freshman et al., The Lawyer-Negotiator as Mood Scientist: What We Know and Don't Know About How Mood Relates to Successful Negotiation, 2002 J. DisP. 
negotiation. ${ }^{28}$ The degree to which a negotiator can navigate this particular part of negotiation is called social intuition. ${ }^{29}$ Social intuition in negotiation is the combination of emotional and social intelligence ${ }^{30}$ regarding yourself, your counterpart, and the situation in which you are negotiating - the context. This subject brings together verbal, paraverbal, and nonverbal elements of negotiation that should be tracked in order to be effective. ${ }^{31}$

\section{Why This Skill Matters in Negotiation}

Communication researchers estimate that close to 93 percent of communication occurs through nonverbal communication. ${ }^{32}$ More effective negotiators can track nonverbal cues throughout the negotiation. Key elements of nonverbal communication include eye contact, facial expressions, ${ }^{33}$ body language (e.g., arms crossing, gestures, leaning in, fidgeting, etc.), physical contact (particularly in greeting, like handshakes ${ }^{34}$ ), and proximity of the parties (i.e., seating arrangement). ${ }^{35}$

RESOL. 1, 17-20 (2002); see generally Jennifer M. George \& Erik Dane, Affect, Emotion, and Decision Making, 136 Organizational Behav. \& Hum. Decision Processes 47 (2016) (discussing research on affect, emotion, and decision making in the context of "four topical areas: the influence of incidental mood states and discrete emotions on decision making, the influence of integral affect [sic] on decision making, affect and emotion as a consequence of decision making, and the role of regret in decision making."); Alex Hofer et al., Gender Differences in Regional Cerebral Activity During the Perception of Emotion: A Functional MRI Study, 32 Neurolmage 854, 854-61 (2006) (suggesting, in a study of adults between 20 to 48 years old, that there is "gender-related neural responses to emotional stimuli"); Jennifer S. Mueller \& Jared R. Curhan, Emotional Intelligence and Counterpart Mood Induction in a Negotiation, 17 InT'L J. Conflict MGMT. 110, 112, 118 (2006).

28 Andrea Kupfer Schneider \& Noam Ebner, Social Intuition, in 1 The NegOtiator's DesK REFERENCE, supra note 26, at 129-30.

${ }^{29}$ Id. at 131; see generally Matthew D. Lieberman, Intuition: A Social Cognitive Neuroscience Approach, 126 PsychOL. BuLL. 109 (2000).

30 See Daniel Goleman, Emotional Intelligence 42 (1995); Daniel Goleman \& Richard Boyatzis, Social Intelligence and the Biology of Leadership, Harv. Bus. Rev., Sept. 2008, at 74; Daniel Goleman et al., Primal Leadership: The Hidden Driver of Great Performance, Harv. Bus. ReV., Dec. 2001, at 42, 44-49.

31 See generally Dejun Tony Kong et al., Negotiators' Emotion Perception and ValueClaiming Under Different Incentives, 27 InT'L J. ConfliCt MGMT. 146 (2016) (finding that, in a study of college students, higher skill at emotional intelligence led to better negotiation results, even in value-claiming scenarios).

32 Jeff Thompson et al., Nonverbal Communication in Negotiation, in 1 The Negotiator's DESK REFERENCE, supra note 26, at 451; see also Albert Mehrabian, Some Referents and Measures of Nonverbal Behavior, 1 BeHAV. Res. MEthods \& InSTRUMENTATION 203 (1969).

33 See Rod A. Martin et al., Emotion Perception Threshold: Individual Differences in Emotional Sensitivity, 30 J. Res. Personality 290, 293 (1996).

34 See Juliana Schroeder et al., Handshaking Promotes Deal-Making by Signaling Cooperative Intent, 116 J. PERSONALITY \& SOC. PSYCHOL. 743, 748-49 (2019).

35 See id.; see generally Elisha Babad et al., Nonverbal Communication and Leakage in the Behavior of Biased and Unbiased Teachers, 56 J. Personality \& Soc. Psychol. 89, 90 (1989). 
Additional communication cues can be found in the audio (paraverbal) of the negotiation even without examining the words. ${ }^{36}$ The pace and volume of our speech signals everything from excitement to boredom to nervousness. ${ }^{37}$ Similarly, the tone of the voice is often a signal for mood and emotion. ${ }^{38}$ Even the length of pauses in between words are something to which we want to pay attention. ${ }^{39}$

Finally, separate from the actual content of the words, other parts of verbal communication give us additional cues in the negotiation. Humor can show comfort or nervousness or can reflect a counterpart's view of the negotiation. ${ }^{40}$ Consider the difference between a negotiator that starts off with a selfdeprecating joke versus one who starts with a joke at the other's expense. ${ }^{41}$ Similarly, the types of metaphors and similes used by negotiators give further insight into how a negotiator views the interaction. ${ }^{42}$ Negotiators may not walk into a room and announce that they feel under attack, but a war metaphor where the negotiator announces he is ready to storm the castle or that his client has put on his armor reveals his thinking. Effective negotiators think carefully about how metaphors reflect their current viewpoint or could be modified.

There are three key parts of social intuition-paying attention to yourself, reading your counterpart, and then bridging between the two of you. The first part of social intuition in action is the ability to know and read oneself in the course of the negotiation. Our ability to recognize our own patterns of behavior in this instance is the first step toward the elusive emotional intelligence so

36 See Thompson et al., supra note 32 , at 450.

37 See Schneider \& Ebner, supra note 28, at 136; see generally Yaacov J. Rose \& Warren W. Tryon, Judgments of Assertive Behavior as a Function of Speech Loudness, Latency, Content, Gestures, Inflection, and Sex, 3 BeHAV. ModifiCATION 112 (1979).

38 Thompson et al., supra note 32, at 460; see Jessica L. Lakin \& Tanya L. Chartrand, Using Nonconscious Behavioral Mimicry to Create Affiliation and Rapport, 14 PsYchOL. SCI. 334, 336 (2003); see also Debi LaPlante \& Nalini Ambady, On How Things Are Said: Voice Tone, Voice Intensity, Verbal Content, and Perceptions of Politeness, 22 J. LANGuAge \& SOC. PSYCHOL. 434 (2003).

39 See Thompson et al., supra note 32, at 454-55.

40 See Andrea Kupfer Schneider, Effective Responses to Offensive Comments, 10 NeGOT. J. 107, 111-12 (1994).

41 See Eiman Azim et al., Sex Differences in Brain Activation Elicited by Humor, 102 PNAS 16496, 16501 (2005) (noting that further study is needed to understand gender differences in responding to humor).

42 See Howard Gadlin et al., The Road to Hell Is Paved with Metaphors, in 2 THE Negotiator's Desk Reference, supra note 6, at 3; Jonathan R. Cohen, Adversaries? Partners? How About Counterparts? On Metaphors in the Practice and Teaching of Negotiation and Dispute Resolution, 20 Conflict Resol. Q. 433, 438 (2003); Jayne Seminare Docherty, Narratives, Metaphors, and Negotiation, 87 MARQ. L. REV. 847, 851 (2004). See generally antonio R. Damasio, Descartes' Error: Emotion, Reason, and the Human Brain (1994) (discussing the importance of metaphors in reflecting emotion). 
highly rated for leadership. ${ }^{43}$ What are the cues conveyed through our eye contact and body language? ${ }^{44}$ How fast are we talking and what metaphors are we using? This self-awareness is key to the effective use of social intuition on our behalf. ${ }^{45}$

The next piece of this puzzle is to be able to read the other party during the negotiation. What does their body language signal? What does that smile mean? Does the quickening of their speaking mean excitement about the deal or a desire to gloss over important terms? Strong negotiators will build this awareness in order to gain insight into their emotional state and their sense of how the negotiation is proceeding. ${ }^{46}$

43 See Richard Boyatzis \& Annie McKee, Resonant Leadership 4, app. at 205-06 (2005) (arguing that self-control, awareness, emotional intelligence, and compassion for others are key to leadership); LARRY JoHnson \& BoB PhILliPs, ABSOLUTE Honesty: Building a Corporate Culture That Values Straight Talk AND Rewards Integrity 257 (2003) (arguing for ethical structures and integrity in leadership); HARRY M. JANSEN KRAEMER JR., Becoming The Best: Build a World-Class Organization Through Values-Based LEADERSHIP 58 (2015) (describing the best leaders as self-reflective and humble); ROBERT I. Sutton, The No Asshole Rule: Building a Civilized Workplace and Surviving One THAт ISN'T 59 (2007) (noting that the best leaders are ones who enforce a "jerk-free" rule and do not tolerate destructive arrogance); see also GolEMAN, supra note 30, at 41; Goleman \& Boyatzis, supra note 30, at 74; Gulcimen Yurtsever et al., Gender Differences in BuyerSeller Negotiations: Emotion Regulation Strategies, 41 Soc. Behav. \& Personality 569, 571, 573-74 (2013) (finding more negotiation success by managers-regardless of genderwho demonstrated self-control and emotional regulation); Geoff Colvin, Humans Are Underrated, FORTUNE (July 23, 2015), http://fortune.com/2015/07/23/humans-are-underrated/ [https://perma.cc/UW2X-XC65].

${ }^{4}$ See Beatrice de Gelder, Why Bodies? Twelve Reasons for Including Bodily Expressions in Affective Neuroscience, 364 Phil. Transactions Royal Soc'y B 3475, 3478 (2009) (arguing that reading body language is as important as facial expressions).

45 Juliana Schroeder \& Nicholas Epley, The Sound of Intellect: Speech Reveals a Thoughtful Mind, Increasing a Job Candidate's Appeal, 26(6) PsYCHOL. SCI. 877, 877, 879 (2015) (noting in a study with $18 \mathrm{MBA}$ students, "the unique importance of a person's voice, over and above the semantic content of the person's language, for understanding the contents of his or her thoughts. Because of the paralinguistic cues in voice, such as intonation, cadence, and amplitude, observers who hear communicators guess their actual thoughts and feelings more accurately than observers who read the exact same words in text."); Elizabeth Baily Wolf et al., Managing Perceptions of Distress at Work: Reframing Emotion as Passion, 137 Organizational Behav. \& Hum. Decision Processes 1, 1 (2016) (finding that the adult "participants were more likely to hire job candidates and choose collaborators who reframed their distress as passion compared to those who did not"); Daniel R. Ames \& Abbie S. Wazlawek, How to Tell If You're a Jerk at Work, Wall Street J. (Feb. 22, 2015, 11:10 PM), https://www.wsj.com/articles/how-to-tell-if-youre-a-jerk-at-work-1424664623 [https:// perma.cc/J75M-958Y] (discussing a lack of self-awareness can harm you in the work place); Goleman et al., supra note 30, at 44 (explaining that self-awareness is key to effective leadership).

46 See Christine Ma-Kellams \& Jennifer Lerner, Trust Your Gut or Think Carefully? Examining Whether an Intuitive, Versus a Systematic, Mode of Thought Produces Greater Empathetic Accuracy, 111 J. Personality \& Soc. Psychol. 674 (2016) (arguing that empathetic accuracy is increased by systematic thought). 
The final piece of social intuition is the ability to use awareness of oneself and of the counterpart to bridge and smooth out the negotiation process. As Abraham Lincoln said, "Tact is the ability to describe others as they see themselves." ${ }^{47}$ In psychology and biology, this process is often focused on mirroring - our natural tendency to match body language cues (they lean in, we lean in, etc.). ${ }^{48}$ This mirroring has the effect of unconsciously building rapport with our counterpart. ${ }^{49}$ When we do this purposively - matching our tone or pace; mirroring body language; working with the metaphors that they have used-we can build a connection with our counterpart. ${ }^{50}$

\section{Differences That Are Found}

There are a plethora of studies that conclude that women are more skilled than men in the variety of elements that fall under social intuition in terms of reading the counterpart. (In terms of self-awareness, the first element of social intuition, there does not appear to be studies on gender differences but there are such studies on the related traits of self-control and the ability to be patient. In these studies, women have been found to have a higher level of self-control. ${ }^{51}$ )

Women are generally thought to be better than men at reading nonverbal signals, and the studies back up this conclusion. First, women are typically bet-

47 Brittany C. Solomon \& Simine Vazire, Knowledge of Identity and Reputation: Do People Have Knowledge of Others' Perceptions?, 111 J. Personality \& Soc. Psychol. 341, 341 (2016) (quoting Abraham Lincoln).

48 See Kelly Schwind Wilson et al., Personality Similarity in Negotiations: Testing the Dyadic Effects of Similarity in Interpersonal Traits and the Use of Emotional Displays on Negotiation Outcomes, 101 J. APPLIED PSYCHOL. 1405, 1418 (2016) (finding that being similarly high or low on agreeableness with the other negotiator leads to shorter negotiations, less conflict, and a more positive evaluations of one's counterpart); Shankar Vedantam, How Brain's 'Mirrors' Aid Our Social Understanding, WASH. Post (Sept. 25, 2006), http://www. washingtonpost.com/wp-dyn/content/article/2006/09/24/AR2006092400718.html?noredirect $=$ on [https://perma.cc/Z8E2-WKY7].

49 See generally Jeroen Stouten \& David De Cremer, "Seeing is Believing”: The Effects of Facial Expressions of Emotion and Verbal Communication in Social Dilemmas, 23 J. BeHAV. DeCision MAKING 271, 271 (2010) (finding "that if the other person displayed happiness he or she was perceived as honest, trustworthy, and reliable, and cooperation was increased when verbal communication was cooperative rather than self-interested").

50 Schneider \& Ebner, supra note 28, at 130; Petri Laukka et al., The Expression and Recognition of Emotions in the Voice Across Five Nations: A Lens Model Analysis Based on Acoustic Features, 111 J. Personality \& Soc. Psychol. 686, 687 (2016) (finding that culture impacts ability to pick up tonal cues); see Jeremy A. Yip \& Maurice E. Schweitzer, Mad and Misleading: Incidental Anger Promotes Deception, 137 Organizational Behav. \& Hum. DeCision Processes 207, 213 (2016) (discussing that building social intuition can also be a defensive move in negotiation).

51 See Lori Verstegen Ryan, Sex Differences Through a Neuroscience Lens: Implications for Business Ethics, 144 J. Bus. ETHICs 771, 779-80 (2017) (suggesting that females and males think and behave differently in ethical situations because of the effects of the hormones in the system). 
ter able to decode body language, tone, ${ }^{52}$ and facial expressions. ${ }^{53}$ Women are better able to read smiles ${ }^{54}$ and better able to read eye contact. ${ }^{55}$ Women are also better able to read emotion through these nonverbal cues. ${ }^{56}$ Interestingly, men are better at reading threatening cues but will often miss other emotions that are conveyed through these nonverbal cues. ${ }^{57}$

52 See Annett Schirmer et al., Listen Up! Processing of Intensity Change Differs for Vocal and Nonvocal Sounds, 1176 BRAIN RES. 103, 110 (2007) (finding, in a study of undergraduate students, that women were more sensitive to vocal shifts).

53 See Monika Gulabovska \& Peter Leeson, Why Are Women Better Decoders of Nonverbal Language?, 31 GENDER IssuES 202, 209, 211 (2014) (discussing that women were found to be superior nonverbal decoders compared to men in a study of male and female undergraduate students); see also Cezary Biele \& Anna Grabowska, Sex Differences in Perception of Emotion Intensity in Dynamic and Static Facial Expressions, 171 EXPERIMENTAL BRAIN RES. 1, 2-6 (2006) (finding in a study of males and females ages 20-24 that females were better than men at detecting intensity of both anger and happiness in dynamic expressions); Uta-Susan Donges et al., Women's Greater Ability to Perceive Happy Facial Emotion Automatically: Gender Differences in Affective Priming, 7 PLOS ONE 1, 1-2 (2012) (finding in a study of 81 males and females averaging the age of 25 that "[w]omen seem to have a greater ability to perceive and respond to positive facial emotion at an automatic processing level compared to men."); Nancy Eisenberg et al., Sympathy and Personal Distress: Development, Gender Differences, and Interrelations of Indexes, 44 NEW DIRECTIONS FOR CHILD \& Adolescent Dev. 107, 119 (1989); Barbara Montagne et al., Sex Differences in the Perception of Affective Facial Expressions: Do Men Really Lack Emotional Sensitivity?, 6 Cognitive Processing 136, 136 (2005) (finding, in a study of 68 undergraduate students, "that men were less accurate, as well as less sensitive in labelling facial expressions."). But see Gina M. Grimshaw et al., A Signal-Detection Analysis of Sex Differences in the Perception of Emotional Faces, 54 BRAIN \& COGNITION 248, 248 (2004) (finding no gender differences in discerning facial expressions in a study of university students); Marina Pavlova, Perception and Understanding of Intentions and Actions: Does Gender Matter?, 449 NeuroscienCe LetTERS 133, 134 (2009) (stating that in a study of teenagers interpreting a comic strip, no gender differences were found).

54 See generally Maren Spies \& A. Timur Sevincer, Women Outperform Men in Distinguishing Between Authentic and Nonauthentic Smiles, 158 J. Soc. PsychOL. 574 (2018) (finding that women were better than men in identifying authentic versus nonauthentic smiles).

55 See Boris Schiffer et al., Why Don't Men Understand Women? Altered Neural Networks for Reading the Language of Male and Female Eyes, 8 PLOS ONE 1, 1-2 (2013) (finding "that men actually had twice as many problems in recognizing emotions from female as compared to male eyes" in a study of single men ages $21-52$ years old).

56 See Arseny A. Sokolov et al., Gender Affects Body Language Reading, 2 FronTIERS PsYchol. 1, 4 (2011) (finding that, in a study of adults, women were better able to perceive "neutral" knocking on doors (versus happy or angry knocking)); Ashley E. Thompson \& Daniel Voyer, Sex Differences in the Ability to Recognise Non-Verbal Displays of Emotion: A Meta-analysis, 28 Cognition \& EMOTION 1164, 1165-66 (2014) (evaluating the data collected in other studies and finding women to be better than men at tasks measuring one's ability to recognize nonverbal emotional cues).

57 See generally Matthew J. Hertenstein \& Dacher Keltner, Gender and the Communication of Emotion Via Touch, 64 SEX Roles 70, 74 (2011) (finding that men are better than women at communicating anger through nonverbal cues while women were better able to communicate sympathy and happiness through nonverbal cues); see also Coreen Farris et al., Perceptual Mechanisms That Characterize Gender Differences in Decoding Women's Sexual Intent, 19 Psychol. SCI. 348, 348-49 (2008) (finding, in a study of 280 undergraduate 
Numerous studies have been done showing that women are better able to manage the mood and tone of the interaction. Women are better able to mirror and smooth the interaction - they are better at maintaining eye contact and smiling. ${ }^{58}$ Many women have been trained to host and tend to others' needsthis is a socially expected skill - and so setting the mood in the negotiation may come more naturally. ${ }^{59} \mathrm{In}$ fact, in looking at the mood of negotiations in mixed gender pairs, anger is more likely to be common when males negotiate while happiness is only common between pairs of women negotiating. ${ }^{60}$

Another element of social intuition is physical contact and body language during greetings and interactions. ${ }^{61}$ Studies have shown that brief touches can result in higher tips for waitstaff in restaurants. ${ }^{62}$ Yet currently in US culture it is customary that men barely touch one another, except perhaps in sports ${ }^{63}$ and, in mixed gender pairs, this interaction should be left up to the woman. Men often culturally hold back from touching their male counterparts and mostly un-

students, that men are more likely than women to mix up social cues- "men were more likely than women to misperceive friendliness as sexual interest, but they also were quite likely to misperceive sexual interest as friendliness."); Hofer et al., supra note 27, at 855, 861 (finding differences in brain scans of adults regarding the perception of emotion); M.E. Kret \& B. De Gelder, A Review on Sex Differences in Processing Emotional Signals, 50 NeUROPSYCHOLOGIA 1211, 1212 (2012) (assessing outside evidence and suggesting that women are better than men at expressing themselves and recognizing emotions).

58 See Marianne LaFrance et al., The Contingent Smile: A Meta-Analysis of Sex Differences in Smiling, 129 Psychol. Bull. 305, 313, 326 (2003) (finding, in a meta analysis of 162 research reports, women smile more than men); Lori Spangler, Gender-Specific Nonverbal Communication: Impact for Speaker Effectiveness, 6 Hum. Resource Dev. Q. 409, 412 (1995) (discussing research that has indicated "women tend to smile more frequently, have more eye contact, and take up less space in proportion to their body size than men, while men initiate touch and interrupt more often than women.") (quoting NANCY HENLEY, BODY Politics: Power, SeX, AND NONVERbal COMmunication (1977)).

59 See Claire Cain Miller, Women Actually Do Govern Differently, N.Y. TimES (Nov. 10, 2016), https://www.nytimes.com/2016/11/10/upshot/women-actually-do-govern-differently. html [https://perma.cc/Y9SR-TAEX ] (finding that women tend to be more collaborative and bipartisan).

60 See Hertenstein \& Keltner, supra note 57, at 70 (studying male and female undergraduate students and finding that anger was communicated at greater levels only when there was at least one male participant and sympathy was communicated at greater levels only when there was at least one female participant).

${ }^{61}$ Richard Heslin \& Tari Alper, Touch: A Bonding Gesture, in 11 NONVERBAL INTERACTION 47, 50 (John M. Wiemann \& Randall P. Harrison eds., 1983); see also William F. Chaplin et al., Handshaking, Gender, Personality, and First Impressions, 79 J. Personality \& Soc. PsYCHOL. 110, 116 (2000).

62 See April H. Crusco \& Christopher G. Wetzel, The Midas Touch: The Effects of Interpersonal Touch on Restaurant Tipping, 10 Personality \& Soc. Psychol. Bull. 512, 515 (1984); Hertenstein \& Keltner, supra note 57, at 76.

63 See Andrew Reiner, The Power of Touch, Especially for Men, N.Y. Times (Dec. 5, 2017), https://www.nytimes.com/2017/12/05/well/family/gender-men-touch.html [https://perma.cc/ BS9R-5W4R]. 
derstand that they should hold back from touching their female counterparts. ${ }^{64}$ Herein lies an opportunity for women to use touch, according to their own comfort level, to build rapport. Brief touches, greetings (the two-handed hand shake or the one-handed shake, other arm to pat shoulder, etc.) can be used for bridging the negotiation and establishing more rapport. ${ }^{65}$

Another potential negotiation tool is the use of flattery to build rapportand this particular skill is also much more socially accepted and utilized by women in negotiation. ${ }^{66}$ We know that flattery works even when the recipient knows that they are being flattered. ${ }^{67}$ This adds to the positive mood setting and schmoozing that can create a connection and smooth the negotiation. And it is still socially easier for women to compliment clothes, hair, shoes, and general looks. Men tend not to do this in mixed gender pairs (at least with acquaintances) and generally do not engage in this kind of pro-social behavior among single gender pairs. ${ }^{68}$ Even conversations about children and spouses tend to be easier among female acquaintances. ${ }^{69}$

\section{Future Research Directions}

There are several conclusions to draw about the research in social intuition. First, we need more studies in general for how these skills can be utilized in negotiation. While the leadership, counseling, and other business literature stress the importance of these skills, we need more studies in the context of negotiation. And as women seem to far exceed men in these tasks, ${ }^{70}$ we need studies that examine how these advantages play out in negotiation. Finally, some skills of social intuition have been well-studied (i.e., reading expressions or emotion) while others could use more attention to truly understand how social intuition influences the results in a negotiation.

64 See id.

65 See Chaplin et al., supra note 61, at 116 (noting that women can benefit from giving a firm handshake in greeting).

66 See Nan Sun, Gender-Based Differences in Complimenting Behaviour: A Critical Literature Review, 5 ANU UNDERGRADUATE RES. J. 213, 221 (2013).

67 See id. at 218.

68 Janet Holmes, Paying Compliments: A Sex-Preferential Politeness Strategy, $12 \mathrm{~J}$. Pragmatics 445, 445, 458 (1988) (finding this based on study of New Zealanders); Janie Rees-Miller, Compliments Revisited: Contemporary Compliments and Gender, $43 \mathrm{~J}$. PRAGMATICS 2673, 2680 (2011).

69 Jerome R. Sehulster, Things We Talk About, How Frequently, and to Whom: Frequency of Topics in Everyday Conversation as a Function of Gender, Age, and Marital Status, 119 Aм. J. Psychol. 407, 413-14 (2006); Fiona Sheridan, Gender, Language and the Workplace: An Exploratory Study, 22 Women MgMt. Rev. 319, 322 (2007).

${ }^{70}$ See Sehulster, supra note 69, at 413-14. 


\section{B. Empathy}

Empathy is a second key negotiation skill and refers to the ability to cognitively assess what your negotiation counterpart is both thinking and feeling. ${ }^{71}$ Different scholars define empathy slightly differently. Social scientists, for example, use the term "perspective taking" to describe the understanding of the other side. ${ }^{72}$ Yet this does not seem to include understanding their emotions. Jennifer Brown divides empathy into "cognitive understanding [versus] emotional connection and resonance" which seems to merge social intuition with empathy. ${ }^{73}$ For the purposes of this article, empathy will be the cognitive understanding of the counterpart's needs, motives and emotions. Note that empathy is different than social intuition as the focus is on the cognitive understanding of the counterpart rather than reading them. These skills are linked-social intuition helps us understand their emotions - but it is helpful to these to distinguish what the negotiator needs to do in order to be effective. ${ }^{74}$ Empathy, often demonstrated by active listening and respectful questions, helps us to understand what our counterpart is thinking in each moment and, therefore, helps us to determine what strategies or skills will be needed in order to change their mind. With empathy, for example, we could better frame our arguments to be persuasive to our counterpart. ${ }^{75}$ With empathy, we can understand what his or her priorities are (or are not) and better package trade-offs in order to make a deal that meets our priorities. With empathy, we can also better maneuver around any hazards - elements that might make the counterpart particularly de-

71 Roman Krznaric, Empathy: Why It Matters, AND How to Get It, at x (2014); see also Roger Fisher \& Daniel Shapiro, Beyond ReAson: Using Emotions as You Negotiate (2006); RANDAll Kiser, Soft Skills for the EfFective LaWYer 160 (2017); Robert H. Mnookin et Al., Beyond Winning: Negotiating to Create Value in Deals AND Disputes 9-10 (2000); ANDREa Kupfer Schneider \& DAVid Kupfer, SMART \& Savvy: Negotiation Strategies in ACAdemia 39 (2017); Adam D. Galinsky et al., Why It Pays to Get Inside the Head of Your Opponent: The Differential Effects of Perspective Taking and Empathy in Negotiations, 19 PSYCHOL. SCI. 378, 383 (2008) (studying seventy Master in Business Administration students and discussing how empathy is an essential negotiation tool).

72 See Adam D. Galinsky et al., Power and Perspectives Not Taken, 17 PsychOL. ScI. 1068, 1068 (2006) (demonstrating that psychological literature refers to this skill as perspective taking); Debra Gilin et al., When to Use Your Head and When to Use Your Heart: The Differential Value of Perspective-Taking Versus Empathy in Competitive Interactions, 39 Personality \& Soc. Psychol. Bull. 3, 4 (2013).

73 Jennifer Gerarda Brown, Deeply Contacting the Inner World of Another: Practicing Empathy in Values-Based Negotiation Role Plays, 39 WASH. U. J.L. \& POL'Y 189, 194-95 (2012).

74 Id. at 196.

75 Id. at 196; Donna Shestowsky, The Psychology of Negotiation: Using Persuasion to Negotiate More Effectively, in 1 THE NeGOTIATOR's DESK REFERENCE, supra note 26, at 339, 346; James H. Stark \& Douglas N. Frankel, Changing Minds: The Work of Mediators and Empirical Studies of Persuasion, 28 OHIO ST. J. DisP. RESOL. 263, 266-67 (2013). 
fensive - or determine that we need to face those and deal with those concerns immediately. ${ }^{76}$ It gives us a roadmap of how to conduct the negotiation.

\section{Why This Skill Matters in Negotiation}

How can a negotiator build and operationalize empathy? Some negotiators may already be able to empathize with the other lawyer or client. Perhaps a similar situation occurred to them or a close family member; perhaps they are naturally better at guessing how the other might be feeling. In order to increase empathic accuracy, negotiators need to engage in certain behaviors before and during the negotiation. In advance, effective negotiators will research the other party and prepare for the negotiation by making educated guesses about their interests and priorities. ${ }^{77}$ During the negotiation, we should engage in empathy, and continue to research the counterpart's interests, by asking questions and carefully listening to them. Many counseling and negotiation textbooks spend a significant amount of time discussing different types of questions ${ }^{78}$ and strong listening skills. ${ }^{79}$ This is wise, given the research that shows how important strong listening skills are in developing relationships by demonstrating empathy. (Listening is also crucial for gathering the information one needs to conduct the negotiation. ${ }^{80}$ ) So it should be no surprise that better listeners are better

76 Fisher \& SHAPIRO, supra note 71, at 190; Jeneen Interlandi, The Brain's Empathy Gap, N.Y. Times MAG. (Mar. 19, 2015), https://www.nytimes.com/2015/03/22/magazine/the-brain s-empathy-gap.html [https://perma.cc/MSW3-PWWZ] (explaining how empathy can overcome bias). For an example of how challenging it is to train people in conflict to have empathy for others, see Gábor Simonovits et al., Seeing the World Through the Other's Eye: An Online Intervention Reducing Ethnic Prejudice, 112 AM. PoL. SCI. REV. 186, 191-92 (2018).

77 Roger Fisher \& William Ury, Getting to Yes: Negotiating Agreement Without GIVING IN 44 (Bruce Patton ed., 2d ed. 1991); Leonard L. Riskin, Annual Saltman Lecture: Further Beyond Reason: Emotions, The Core Concerns, and Mindfulness in Negotiation, 10 NEV. L.J. 289, 301 (2010).

78 NeIL RACKHAM, SPIN SELLING 92-93 (1988) (outlining the most effective type of questions).

79 See, e.g., Stefan H. Krieger \& Richard K. Neumann, Jr., Essential Lawyering Skills: Interviewing, Counseling, Negotiation, and Persuasive Fact ANalysis 49-50 (4th ed. 2011); Carrie J. Menkel-Meadow et al., Dispute Resolution: Beyond the Adversarial Model 153 (2005); Carrie J. Menkel-Meadow et al., Negotiation: Processes for Problem Solving 297 (2006); LeONARd L. Riskin et AL., Dispute Resolution ANd Lawyers 143 (4th ed. 2009); Jonathan R. Cohen, "Open-Minded Listening”, 5 CHARlotte L. ReV. 139, 139 (2014); Neil Hamilton, Effectiveness Requires Listening: How to Assess and Improve Listening Skills, 13 Fla. CoASTAL L. ReV. 145, 146 (2012); Jack Zenger \& Joseph Folkman, What Great Listeners Actually Do, HaRv. Bus. Rev. (July 14, 2016), https://hbr.org/2016/07/what-great-listeners-actually-do [https://perma.cc/CU4EYA3T].

${ }^{80}$ Tal Eyal et al., Perspective Mistaking: Accurately Understanding the Mind of Another Requires Getting Perspective, Not Taking Perspective, 114 J. PersonAlity \& Soc. Psychol. 547,547 (2018) (finding that "[i]ncreasing interpersonal accuracy seems to require gaining new information rather than utilizing existing knowledge about another person" in a study of undergraduate students). 
liked. ${ }^{81}$ Most importantly in negotiation, studies have now shown that changing the counterpart's mind is more likely to occur when one has listened to him or her ${ }^{82}$ So strong listening skills will actually be more helpful than strong talking skills. ${ }^{83}$ Finally, empathy is the skill to read the emotions of the other party. This is the cognitive side of social intuition where we identify the current emotion of the counterpart and also think carefully about the issues in the negotiation to predict where emotions may or may not arise. ${ }^{84}$

\section{Differences That Are Found}

Much like social intuition, here too, women have a higher skill level. Women are measured as better listeners ${ }^{85}$ and are less likely to interrupt. And, like the related studies in social intuition, women are better able to read the emotion of body language used in a conversation. ${ }^{86}$ This allows women to be

81 Karen Huang et al., It Doesn't Hurt to Ask: Question-Asking Increases Liking, 113 J. Personality \& Soc. Psychol. 430, 430 (2017) (finding that listeners who asked their partners questions led to their partners liking them more); see also Guy Itzchakov et al., I Am Aware of My Inconsistencies but Can Tolerate Them: The Effect of High Quality Listening on Speakers' Attitude Ambivalence, 43 Personality \& Soc. Psychol. Bull. 105, 105 (2017) (suggesting that counterparts who provide high quality listening can change the speaker's attitude structure).

${ }^{82}$ Guy Itzchakov \& Avraham N. Kluger, Listening with Understanding in Negotiation and Conflict Resolution, in 1 THE NegOtIATOR's DeSK ReFERENCE, supra note 26, at 409, 414 (suggesting that counterparts who provide high quality listening can change the speaker's attitude structure); Guy Itzchakov et al., The Listener Sets the Tone: High-Quality Listening Increases Attitude Clarity and Behavior-Intention Consequences, 44 PERSONALITY \& SOC. PSYCHOL. BuLl. 762, 763 (2018) (stating that in a study of 200 adults finding that high quality listening reduces the speaker's social anxiety and leads to greater self-awareness); Guy Itzchakov \& Avraham N. Kluger, The Power of Listening in Helping People Change, HaRv. Bus. REv. (May 17, 2018), https://hbr.org/2018/05/the-power-of-listening-in-helping-people -change [https://perma.cc/NN34-YJ6N].

${ }^{83}$ Stefan H. Krieger, A Time to Keep Silent and a Time to Speak: The Functions of Silence in the Lawyering Process, 80 OR. L. Rev. 199, 266 (2001).

84 Alison Wood Brooks, Emotion and the Art of Negotiation, HaRv. Bus. REV., Dec. 2015, at 57,61 .

${ }^{85}$ Lisa Blue \& Robert B. Hirschhorn, The Psychology of Women's Influence on Juries, 49 Advoc. (TEX.) 47, 47 (2009) ("Because women generally are better listeners, have more patience and have a natural ability to multi-task, they make excellent jurors in many cases."); Hannah Riley Bowles, Psychological Perspectives on Gender in Negotiation, in SAGE HANDBoOK Gender \& Psychol. 465, 469 (Michelle K. Ryan \& Nyla R. Branscombe eds., 2013); Patricia W. Hatamyar \& Kevin M. Simmons, Are Women More Ethical Lawyers? An Empirical Study, 31 Fla. ST. U. L. ReV. 785, 840 (2004) ("Women may, on the whole, be better listeners and easier to be around."); Sheridan, supra note 69, at 322; Wendy Mogel, Should We Speak to Little Boys as We Do Little Dogs?, N.Y. Times (Apr. 10, 2018), https:// www.nytimes.com/2018/04/10/well/family/whos-a-good-boy.html [https://perma.cc/U8K7YWV5] (giving advice to teach boys empathy).

${ }^{86}$ Sokolov et al., supra note 56, at 1 (finding that "females exhibit [a] higher sensitivity to non-verbal cues ... and are more proficient in [the] recognition of facial emotions" in conversation). 
able to empathize with the counterpart and either minimize any negative consequences of that emotion or take advantage of positive emotions.

Often linked to women's perceived higher levels of empathy, early psychological studies argued that women had a higher "ethic of care" than did men. In a famous study in the psychological literature, Carol Gilligan uses the example of Jake and Amy to explain how boys and girls approach problems differently. ${ }^{87}$ The dilemma presented to them was that a man faces a choice when his wife is sick and he cannot afford the drug that would treat her ${ }^{88} \mathrm{He}$ can either steal the drug or let his wife get sicker. ${ }^{89}$ Jake reasons that since a life is worth more than following the law the husband should steal the drug for his wife..$^{90}$ Gilligan calls this the "ethic of justice." 91 On the other hand, Amy, when faced with the same dilemma, starts to "fight the hypo." 92 She does not agree that this scenario is a take-it-or-leave-it dilemma, noting that if the man steals the drug and gets caught, he will not be around anyway to take care of his wife. ${ }^{93}$ Or perhaps the man can negotiate with the druggist for a reduced payment or payment plan if the druggist knew how sick the wife was. ${ }^{94}$ In either case, she does not weigh the value of life versus stealing but rather tries to figure out a way to meet all of the interests. ${ }^{95}$ Gilligan calls this the ethic of care. ${ }^{96}$ And writers throughout the 80s and 90s hypothesized that this ethic of care- this higher level of empathy for the other party - would lead to women being taken advantage of in negotiation. ${ }^{97}$ In other words, if one party knows that the other cares about the relationship, the first party can push the other to give up more goodies in exchange for maintaining a good relationship. Others have argued instead that this "ethic of care" described by Gilligan is actually a sign of better problem-solving skills. ${ }^{98}$ The desire to fight the hypo and meet all interests would demonstrate a willingness to listen to the other side and work things out.

87 Carol Gilligan, In a Different Voice: Psychological Theory and Women's DEVELOPMENT 25, 174 (1982).

${ }^{88} \mathrm{Id}$.

${ }^{89} I d$. at 26.

90 Id.

91 Id. at 174 ("[A]n ethic of justice proceeds from the premise of equality - that everyone should be treated the same....”).

92 Id. at $27-28$.

93 Id at 28.

94 Id. at 29.

95 Id. at 31 .

96 Id. at 174 ("[A]n ethic of care rests on the premise of nonviolence - that no one should be hurt.").

97 See, e.g., Carol M. Rose, Bargaining and Gender, 18 HARV. J.L. \& Pub. Pol'y 547, 557 (1995).

${ }^{98}$ Carrie Menkel-Meadow, Portia in a Different Voice: Speculations on a Women's Lawyering Process, 1 Berkeley Women's L.J. 39, 46-47 (1985). 


\section{Future Research Directions}

In examining the research on empathy and negotiation, the gaps in the research should be noted. These moral development studies cited by Gilligan and others were now conducted over forty-five years ago. ${ }^{99}$ These studies were not conducted in the context of negotiation (nor for the purpose of measuring negotiation skills) $)^{100}$ and so we have been drawing conclusions from that context to another context. And, of course, Amy and Jake were 11-year-olds and not grown-ups. ${ }^{101}$ While we now are starting to see excellent research on how listening skills can be persuasive in changing the other party's attitudes, we do not yet have anything showing how women's advantage in listening skills would impact negotiation outcomes. Even to test that there are not gender differences regarding how empathy operates would be helpful to know.

\section{Ethicality}

A third skill of negotiation effectiveness can be found in the reputation one creates and the trust one is able to establish between the negotiator and the counterpart. Reputation and trust affect both how the negotiation is conducted and the likely compliance with the agreement. ${ }^{102}$ These three elementsreputation, trustworthiness, and trustfulness - are all located under the rubric of "ethicality" and are each separate elements to consider in a negotiation. Wise negotiators will track both their own perceived ethicality as well as that of their counterparts. ${ }^{103}$

99 See Gilligan, supra note 87.

100 See id. at 2-3.

101 Id. at 25.

102 Ronald J. Gilson \& Robert H. Mnookin, Disputing Through Agents: Cooperation and Conflict Between Lawyers in Litigation, 94 Colum. L. REv. 509, 564 (1994); Ricky S. Wong \& Susan Howard, Think Twice Before Using Door-in-the-Face Tactics in Repeated Negotiation: Effects on Negotiated Outcomes, Trust and Perceived Ethical Behaviour, 29 INT'L J. Conflict MGMT. 167, 170 (2018) (studying university students and professionals with negotiation experience and finding that using the door-in-the-face tactic in negotiation leads to less trustworthiness and increases the likelihood of negotiators switching to an alternative partner); see also Eric C. Chaffee, An Interdisciplinary Analysis of the Use of Ethical Intuition in Legal Compliance Decisionmaking for Business Entities, 74 MD. L. REV. 497, 519-23 (2015) (arguing that moral intuition is also part of ethical decisionmaking).

103 See Ernst Fehr \& John A. List, The Hidden Costs and Returns of Incentives-Trust and Trustworthiness Among CEOs, 2 J. EUR. ECO. Ass'N 743, 743-44 (2004) (finding "that CEOs are considerably more trusting and exhibit more trustworthiness than students - thus reaching substantially higher efficiency levels" in transactions). 


\section{Why This Skill Matters in Negotiation}

The first element of ethicality is reputation. ${ }^{104}$ Since negotiations are unpredictable, reputations are used to help manage uncertainty by giving signals and predicting how a negotiator will behave. ${ }^{105}$ In one study examining lawyers, lawyers who had negotiated with each other before were more likely to reach agreements the second time- even if their first negotiation had not ended in agreement. ${ }^{106}$ Reputation helps to explain actions or motivations in a negotiation, particularly when the counterpart does not have full information about one's options or priorities. For example, if a negotiator has a reputation for working well with others, her actions will be interpreted in that "halo" of a cooperative reputation. ${ }^{107}$ When parties have the reputation for being more problem-solving, the result will be more integrative leaving both parties better off ${ }^{108}$ - even if that reputation is unknown to the reputation owner. Counterparts facing negotiators with good reputations will be more inclined to share information and to share it earlier and with more detail. ${ }^{109}$ (This increased information exchange is what leads to more integrative agreements.) And the opposite is also true - reputations for hard bargaining result in poorer agreements for both parties. ${ }^{110}$ Since different reputations lead to different outcomes, a careful negotiator will think about what reputation to build. ${ }^{111}$

The second element of trust is closely linked to reputation. ${ }^{112}$ Trust and distrust are distinct concepts ${ }^{113}$ — one might trust one's counterpart to email back edits to the contract tomorrow but not necessarily trust her to make all the changes one wanted (and therefore a negotiator should doublecheck the draft). Trustworthiness is the part of trust that looks at one's likelihood to do what one has promised - will a negotiator carry out his or her commitments. ${ }^{114}$ It logically follows that when negotiators can trust one another, the negotiation itself

104 See Andrea Kupfer Schneider, Teaching a New Negotiation Skills Paradigm, 39 WASH. U. J.L. \& POL'Y 13, 33 (2012).

105 Catherine H. Tinsley et al., Reputations in Negotiation, in 1 The Negotiator's DesK REFERENCE, supra note 26, at 249, 252-53.

106 Jason Scott Johnston \& Joel Waldfogel, Does Repeat Play Elicit Cooperation? Evidence from Federal Civil Litigation, 31 J. Legal Stud. 39, 40-41 (2002).

107 Catherine H. Tinsley et al., Tough Guys Finish Last: The Perils of a Distributive Reputation, 88 Organizational Behav. \& Hum. Decision Processes 621, 623 (2002).

108 See id. at 635.

$109 C f$. id. (finding counterparts are less likely to share information and be collaborative with those who have poor reputations).

110 Id.

111 See Jennifer E. Stellar \& Robb Willer, Unethical and Inept? The Influence of Moral Information on Perceptions of Competence, 114 J. Personality \& Soc. Psychol. 195, 208 (2018) (finding that perceptions of morality influence perceptions of competence).

112 Schneider, supra note 104, at 33.

113 See Lewicki, Trust and Distrust, supra note 26, at 201.

114 Emma E. Levine et al., Who is Trustworthy? Predicting Trustworthy Intentions and Behavior, 115 J. PERSONALITY \& SOC. PSYCHOL. 468, 469 (2018). 
will be more efficient. Effective negotiators want to build their reputation of trustworthiness. ${ }^{115}$

On the other side of the coin is the concept of trustfulness - the willingness to work with the other side. Effective negotiators recognize that some trust is needed while sharing information in order to find out the elements of the agreement. Too much suspicion or hostility toward one's negotiation counterpart can become a self-fulfilling prophecy ${ }^{116}$ —or might signal to a counterpart that a negotiator is projecting their own misdeeds. Researching into someone's reputation can help determine the level of trust one should have. ${ }^{117}$

\section{Differences That Are Found}

To study the differences in ethicality, most studies have examined expectations of the negotiator (i.e., reputation), moral character, and how different reputation for ethical behavior might play out in a negotiation. ${ }^{18}$ There have been very few studies examining gender differences in negotiations with ethical dilemmas. ${ }^{119}$ Ethical behavior in negotiation can also be linked to the idea of selfcontrol and risk taking. ${ }^{120}$

First, women are presumed to be more ethical and trustworthy. ${ }^{121}$ They have higher levels of moral character ${ }^{122}$ and higher ethical standards. ${ }^{123}$ They

115 See Nancy A. Welsh, The Reputational Advantages of Demonstrating Trustworthiness: Using the Reputation Index with Law Students, 28 NEGOT. J. 117, 139 (2012).

116 See John M. Darley \& Paget H. Gross, A Hypothesis-Confirming Bias in Labeling Effects, 44 J. Personality \& Soc. Psychol. 20, 20 (studying undergraduate students and suggesting that stereotype information creates false biased hypotheses about the stereotyped individual).

117 See Laurie R. Weingart et al., Tactical Behavior and Negotiation Outcomes, 1 InT'L J. Conflict Mgmt. 7, 7-8 (1990); see also Welsh, supra note 115, at 139.

118 See, e.g., Tinsley et al., supra note 105, at 251; Welsh, supra note 115, at 139.

119 But see Art Hinshaw \& Jess K. Alberts, Gender and Attorney Negotiation Ethics, 39 WASH. U. J.L. \& POL'Y 145, 186 (2012) (using gender as a component in a study of attorney negotiation ethics and finding gender differences in how men and women respond to ambiguous ethical situations).

120 See generally RoBBENNOLT \& STERNLIGHT, supra note 26, at 411-14.

121 Jessica A. Kennedy et al., A Social-Cognitive Approach to Understanding Gender Differences in Negotiator Ethics: The Role of Moral Identity, 138 OrganiZATIONAL BeHAV. \& Hum. Decision Processes, 28, 32 (2017) (studying 200 adult participants and finding that women are more likely than men to use more ethical negotiation practices); Maryam Kouchaki \& Laura J. Kray, “I Won't Let You Down:” Personal Ethical Lapses Arising from Women's Advocating for Others, 147 Organizational Behav. \& Hum. Decision Processes 147, 156 (2018) (studying 200 adults and finding that men are more deceptive than women in engaging in morally questionable behaviors when representing themselves).

122 Taya R. Cohen et al., Moral Character in the Workplace, 107 J. Personality \& SoC. Psychol. 943, 957 (2014); Paul J. Zak et al., The Neuroeconomics of Distrust: Sex Differences in Behavior and Physiology, 95 AM. ECON. REv. 360, 363 (2005) (explaining that men have a biological response to feeling distrusted while women did not). 
are less accepting of ethical compromises, ${ }^{124}$ less likely to engage in unethical negotiation tactics, ${ }^{125}$ and more disapproving of the use of deception. ${ }^{126}$ These differences result in interesting consequences-women are both punished more for ethical violations because of these expectations ${ }^{127}$ and women are more likely to be lied to in a negotiation. ${ }^{128}$ Obviously, if one's counterpart is more likely to lie to a negotiator because of gender (or any other assumption) the negotiator needs to protect herself. Strategies like verifying the information one is given, or only sharing information in exchange for other information, etc., will need to be implemented. ${ }^{129}$ And, in fact, women are less trusting than men, perhaps fearing this exploitation. ${ }^{130}$ Yet, a reputation for trustworthiness also

123 George R. Franke et al., Gender Differences in Ethical Perceptions of Business Practices: A Social Role Theory Perspective, 82 J. APPLIED Psychol. 920, 920 (1997) (gathering data from over 20,000 respondents and finding that women are more likely than men to perceive certain business practices as unethical).

124 Jessica A. Kennedy \& Laura J. Kray, Who Is Willing to Sacrifice Ethical Values for Money and Social Status?: Gender Differences in Reactions to Ethical Compromises, 5 Soc. Psychol. \& Personality SCI. 52, 52 (2014) (studying over 100 adults and finding that women reported less interest in jobs than men only when the jobs involved making ethical compromises).

125 Robert J. Robinson et al., Extending and Testing a Five Factor Model of Ethical and Unethical Bargaining Tactics: Introducing the SINS Scale, 21 J. ORGANIZATIONAL BEHAV. 649, $656(2000)$.

126 Anna Dreber \& Magnus Johannesson, Gender Differences in Deception, 99 Econ. LETTERS 197, 198 (2008) (studying undergraduate students and finding that men are more likely than women to lie to secure a monetary benefit).

127 Jessica A. Kennedy et al., Does Gender Raise the Ethical Bar? Exploring the Punishment of Ethical Violations at Work 16 (Vanderbilt Owen Graduate Sch. of Mgmt., Research Paper No. 2770012, 2016), https://papers.ssrn.com/sol3/papers.cfm?abstract_id=2770012 [ht tps://perma.cc/5YXR-Q85E].

128 Kennedy \& Kray, supra note 3, at 5 (reviewing findings from twenty years of research on gender differences in negotiation and discussing findings that show that varying the gender of a counterpart's name, negotiators assume women will be more easily misled than men); see Laura J. Kray et al., Not Competent Enough to Know the Difference? Gender Stereotypes About Women's Ease of Being Misled Predict Negotiator Deception, 125 Organizational Behav. \& Hum. Decision Processes 61, 63-64 (2014) (studying male and female adults and finding in a simulation that women's lower perceived competence explained why they were more easily misled than men).

129 Julia A. Minson et al., Eliciting the Truth, the Whole Truth, and Nothing but the Truth: The Effect of Question Phrasing on Deception, 147 Organizational BeHav. \& Hum. DECISION PROCESSES 76, 76 (2018) (finding the phrasing of the question matters in a study of university students and adults); see Peter Reilly, Was Machiavelli Right? Lying in Negotiation and the Art of Defensive Self-Help, 24 OHIO ST. J. DisP. RESOL. 481, 482 (2009) (discussing that participants in negotiation "must learn how to carefully and purposefully implement strategies and behaviors to defend themselves against those who lie and deceiveno matter the reasons prompting it").

${ }^{130}$ Kyle Irwin et al., Gender, Trust and Cooperation in Environmental Social Dilemmas, 50 Soc. SCI. RES. 328, 328 (2015) (finding that "[W]omen are less trusting and respond to fear incentives in social dilemmas - they are concerned about being exploited .... [And so] women's cooperation is predicated on trust."). 
can result in more problem-solving negotiators being willing to share more information and work out more integrative deals. ${ }^{131}$

A second question concerns gender differences in actual trustworthiness. ${ }^{132}$ Studies of ethical behavior show that making ethical choices is linked to selfcontrol $^{133}$ and that ego depletion can lead to more ethical violations. ${ }^{134}$ If men are more likely to have ego depletion because of less self-control, then it might be assumed they are more likely to violate the ethical norms. When faced with stressful situations (like conflict) men have an increase in testosterone and are more likely to take large risks. ${ }^{135}$ One could analogize lying in a negotiation to taking a flyer on a questionable stock-high risk, high reward. This kind of behavior is more likely to occur with testosterone surges, something men have more than women. ${ }^{136}$ Women's comparative jumps in oxytocin when cooperating in negotiation, for example, could lead to the exact opposite type of ethical behavior (and would be worthy of further research). ${ }^{137}$

A final interesting difference in ethics is whether an ethical violation will impact one's reputation and whether other lawyers will tell their colleagues

131 Leigh L. Thompson, Information Exchange in Negotiation, 27 J. ExPERIMENTAL Soc. PsYCHOL. 161, 163 (1991).

132 See generally Irwin et al., supra note 130 (studying the data of over 2000 survey respondents and discussing that women tend to be less trusting than men).

${ }^{133}$ RobBennolt \& Sternlight, supra note 26, at 411-12; see also MAX H. BAZERMAN \& Ann E. Tenbrunsel, Blind Spots: Why We Fail to Do What's Right and What to Do АвоUт Iт 26-27 (2011) (finding that more ethical decision making takes time, is thoughtful, and cool-headed). In a hilarious study also cited in Bazerman' and Tenbrunsel's book, philosophy professor Eric Schwitzgebel found that ethics books were more likely to be missing from leading academic libraries than non-ethics books. $I d$. at 27.

134 Francesca Gino et al., Unable to Resist Temptation: How Self-Control Depletion Promotes Unethical Behavior, 115 Organizational Behav. \& Hum. Decision Processes 191, 191, 195 (2011) (studying 100 university students and finding that individuals who were "depleted of self-control resources were more likely to behave dishonestly"); Kai Chi Yam et al., Ego Depletion and its Paradoxical Effects on Ethical Decision Making, 124 Organizational Behav. \& Hum. Decision Processes 204, 205 (2014) (studying nearly 900 alumni who graduated with a bachelor's degree in accounting and finding that ego depletion is associated with increased unethical behavior of comparatively low social consensus).

135 Ryan, supra note 51, at 777 (suggesting that the effects of testosterone urge males to think and behave differently); Angela A. Stanton, Hormonal Influence on Male-DecisionMaking: Implications for Organizational Management, in NEUROECONOMICS AND THE FIRM 131, 131-32 (Angela A. Stanton et al. eds., 2010) (discussing how an increase in a male's testosterone levels may lead to an increase in in desire for risk taking).

136 Ryan, supra note 51, at 777.

137 René Riedl et al., Are There Neural Gender Differences in Online Trust? An fMRI Study on the Perceived Trustworthiness of eBay Offers, 34 MIS Q. 397, 420 (2010) (finding that in a study of adults ages 30-35, "women and men recruit different brain areas when facing uncertainty, processing information, and deciding which offer to trust"); Ryan, supra note 51, at 772, 777; Paul J. Zak, The Neurobiology of Trust, ScI. AM., June 2008, at 88, 88 (explaining how increased oxytocin leads to trusting the other party). But see Hinshaw \& Alberts, supra note 119 , at 181 (showing women are equally likely to lie when acting as an agent). 
about it. This type of public shaming and enforcement of norms has only expanded with social media, the internet, and the ability to communicate quickly and broadly. ${ }^{138}$ Studies show that women are more likely to engage in pro social enforcement of norms ${ }^{139}$ - what we might call gossip - and that this enforcement can also be used to protect the negotiator. ${ }^{140}$ (Consider the example of the Media Men list which tried to warn women about certain illegal and harassing negotiation tactics.) ${ }^{141}$ This kind of enforcement can be extremely valuable and can be a strength to the negotiator who uses her networks to research the reputation of her counterpart.

\section{Future Research Directions}

In this area of negotiation skills, much research has been done on the impact of reputation and the outcome of the negotiation. ${ }^{142} \mathrm{We}$ 've also seen research on perceptions of gender and how that ties to reputation. ${ }^{143}$ A missing component would be to examine how this perceived trustworthiness and good reputation operate in an iterated or repeat-play interaction since many of the studies are still done in one-shot interactions. ${ }^{144}$ One could also wonder how reputation for trust interacts with other assumptions about behavior (i.e., appropriate assertiveness) in order to test for effective negotiation skills over time and in the workplace.

\section{Flexibility}

\section{Why This Skill Matters in Negotiation}

To be effective in negotiation, the negotiator needs to be flexible in two different ways. One is process flexibility - being able to shift among styles to find the most effective way to get things done. ${ }^{145}$ This has been well studied in terms of negotiation styles or negotiation approaches and appears to not have

138 Matthew Feinberg et al., The Virtues of Gossip: Reputational Information Sharing as Prosocial Behavior, 102 J. PersonAlity \& Soc. PsYCHOL. 1015, 1016 (2012).

139 Id. at 1020, 1023 (studying male and female undergraduate students and discussing that individuals possessing more prosocial orientations are more likely to engage in gossip).

140 Id. at 1023.

141 Moira Donegan, I Started the Media Men List, CuT (Jan. 10, 2018), https://www.thecut.c om/2018/01/moira-donegan-i-started-the-media-men-list.html [https://perma.cc/PNN9-LNQ L]; see also Jonah Engel Bromwich \& Jaclyn Peiser, Time's Up Co-Founder to Represent 'Media Men' List Creator, N.Y. Times (Oct. 16, 2018), https://www.nytimes.com/2018/10/1 6/style/media-men-list-lawsuit.html [https://perma.cc/R2JV-TAX2].

142 See, e.g., supra text accompanying notes 123-26.

143 See, e.g., supra text accompanying notes 123-26.

144 See, e.g., supra text accompanying notes 123-26.

145 Andrea Kupfer Schneider \& Jennifer Gerarda Brown, Negotiation Barometry: A Dynamic Measure of Conflict Management Style, 28 OHIо ST. J. DisP. RESOL. 557, 557-58 (2013). 
gender differences in negotiation approaches, ${ }^{146}$ yet there could be research about gender differences in terms of ability to shift among them.

The second part of flexibility is to be flexible in outcome-finding more than one way to meet one's needs. ${ }^{147}$ Negotiation literature is filled with exhortations to be more creative, to develop options, and to expand the pie. ${ }^{148}$ Effective negotiators take the time to engage in this creative process in order to find integrative solutions.

\section{Differences That Are Found}

Studies of gender differences that are related to flexibility examine how quickly negotiators make decisions (versus consulting others or percolating over options), the amount of information that negotiators can gather, and how negotiators make decisions in terms of consulting with others.

Studies have found that women take longer to make decisions than men. ${ }^{149}$ If decisions are made too quickly without taking the time to think about what other options might exist, this would obviously limit creativity. A negotiator needs time to brainstorm with one's own team or the client in preparation for the negotiation or to take the time during the negotiation to brainstorm with the negotiation counterpart.

Linked to the speed of decision making is the concept of gathering additional information and consulting with others before deciding. Studies of women and men in leadership roles show that women are more likely to consult and get multiple opinions before deciding. ${ }^{150}$ In addition, as the previous section

146 Andrea Kupfer Schneider, Shattering Negotiation Myths: Empirical Evidence on the Effectiveness of Negotiation Style, 7 HARV. NEGOT. L. REV. 143, 187-88 (2002) (showing no gender differences in style).

147 Markus Kemmelmeier \& Andre P. Walton, Creativity in Men and Women: Threat, Other-Interest, and Self-Assessment, 28 CREATIVITY ReS. J. 78, 78, 80 (2016) (finding little difference in general between the sexes but finding some in specific contexts in a study of undergraduate students).

148 See Carrie Menkel-Meadow, Aha? Is Creativity Possible in Legal Problem Solving and Teachable in Legal Education? 6 HARV. NEGOT. L. REV. 97, 101 (2001); see also Shankha Basu \& Krishna Savani, Choosing One at a Time? Presenting Options Simultaneously Helps People Make More Optimal Decisions than Presenting Options Sequentially, 139 Organizational Behav. \& Hum. Decision Processes 76, 77-78 (2017); Jennifer Gerarda Brown, Creativity and Problem-Solving, 87 MARQ. L. Rev. 697, 703 (2004); Stefan H. Krieger, Domain Knowledge and the Teaching of Creative Legal Problem Solving, 11 Clinical L. Rev. 149, 151-52 (2004); Adam Grant, Kids, Would You Please Start Fighting?, N.Y. Times (Nov. 4, 2017), https://www.nytimes.com/2017/11/04/opinion/sunday /kids-would-you-please-start-fighting.html [https://perma.cc/S5V7-R3ZF].

149 See generally Katty Kay \& Claire Shipman, The Confidence Code: The Science AND Art of Self-Assurance-What Women Should Know 104-05 (2014).

150 See Tomas Chamorro-Premuzic, Why Do So Many Incompetent Men Become Leaders?, HARV. Bus. REV. (Aug. 22, 2013), https://hbr.org/2013/08/why-do-so-many-incompetent-m 
discussed, negotiators who are perceived as more trustworthy and who have better relationships with their negotiation counterparts are more able to gather relevant information from their counterparts. ${ }^{151}$ This additional information can help negotiations craft better solutions ${ }^{152}$ - one will have a better idea of what the counterpart needs and also what they may be able to provide at relatively lower cost. As many negotiation textbooks point out, finding these differences - in willingness to bear risk, in future prediction, in immediate needs, etc. - can result in more integrative and beneficial solutions. ${ }^{153}$ Similarly, additional information can help fuel options that build on common interests. ${ }^{154}$ In either case, the key to successful creativity and flexibility depends on the negotiator having the information she needs in order to propose and craft these options. If women are trusted more (as shown above), they can gather more information. Moreover, if women gather this information to consult with others and design creative options, this comparative strength is even more enhanced. One caveat to a perceived advantage by women is that information gathering can also be linked to networks and, in some fields, women will have less access to supportive networks in order to gather information in advance. ${ }^{155}$

One could also view early studies of psychological differences in gender as differences in flexibility. Recall that, in Carol Gilligan's work, Jake decides that the husband should steal the drug to save his wife while Amy "fights the hypo" and tries to find another way. ${ }^{156}$ Gilligan divided these views into an ethic of justice versus an ethic of care. ${ }^{157}$ But, as Carrie Menkel-Meadow noted in her analysis, another way of viewing this approach to a problem could be the difference in adversarial versus problem-solving approaches. ${ }^{158}$ In other words, Amy was demonstrating the skill of creativity and trying to find a solution that

en [https://perma.cc/KVV3-VSMR] (noting that men do not gather opinions from others). See generally Adam Bryant, Alexa von Tobel of LearnVest: No, Really, What's Your Weakness?, N.Y. Times (Apr. 16, 2015), https://www.nytimes.com/2015/04/19/business/alexa-vo n-tobel-of-learnvest-no-really-whats-your-weakness.html [https://perma.cc/7MLK-7MBB].

151 See supra Section I.A.1.

152 Josh Hyatt, Engineering Inspiration, NEwSwEEK, June 14, 2010, at 1 (discussing the importance of information gathering for creativity).

153 See Lax \& Sebenius, supra note 20, at 243; Michael L. Moffit, Dispute as Opportunities to Create Value, in The Handbook of Dispute Resolution 173, 173 (Michael L. Moffitt and Robert C. Bordone eds., 2005).

154 See LaX \& SEBENIUS, supra note 20, at 243; Moffit, supra note 153, at 174.

155 Brant R. Burleson et al., Are Gender Differences in Responses to Supportive Communication a Matter of Ability, Motivation, or Both? Reading Patterns of Situation Effects Through the Lens of a Dual-Process Theory, 59 CoMM. Q. 37, 37-38 (2011) (studying undergraduate students and discussing that although women may have less access to supportive networks, women possess a greater ability and motivation to process information about support situations and messages).

156 GiLligan, supra note 87, at 26-28.

157 Id. at 30.

158 See Menkel-Meadow, supra note 98, at 50. 
met all of the relevant parties' needs. ${ }^{159}$ In fact, as Menkel-Meadow argues, this is the quintessential skill of lawyering. ${ }^{160}$

\section{Future Research Directions}

Research showing gender differences at this point focus more on the process that is needed for creativity (consulting, gathering information, etc.) and not on the timing needed for creativity (or decision-making under pressure) so that would be one avenue of future research. More research into creativity in the context of negotiation would also be beneficial. Few gender differences have been found in overall creativity. ${ }^{161}$ Rather, there are differences in the routes to creativity (perhaps explaining in part why diverse teams are more creative). ${ }^{162}$ This would be an additional avenue of research for the future.

\section{E. Assertiveness}

Assertiveness is the most well-studied and well-examined skill in negotiation. The willingness to ask, the ability to persuade, and the capacity to get what you want are the subject of numerous negotiation best-sellers. ${ }^{163}$ Similarly, the gender differences found over the years related to this skill have focused the largest amount of attention on whether men and women are of equal ability in negotiation.

\section{Why This Skill Matters in Negotiation}

Assertiveness is comprised of two components-knowledge and presentation. ${ }^{164}$ One has to be able to persuade - whatever the substance is that one is asking for - and one also needs to sufficiently prepare so that one is competent to discuss the substance of the ask. Effective negotiators will prepare on several different elements of the negotiation. First, they will understand their own in-

159 Id. at 46.

160 Id. at 46-47.

161 See Burleson et al., supra note 155, at 39.

162 Anna Abraham, Gender and Creativity: An Overview of Psychological and Neuroscientific Literature, 10 BRAIN IMAGING \& BEHAV. 609, 609 (2016) ("[D]ifferences between men and women in creative cognition are best explained with reference to the gender-dependent adopted strategies or cognitive style when faced with generative tasks."); John Baer, Gender Differences in the Effects of Extrinsic Motivation on Creativity, 32 J. CREATIVE BeHAV. 18, 18 (1998).

163 Herb Cohen, You Can Negotiate Anything 20 (1980); G. Richard Shell, Bargaining for Advantage: Negotiation Strategies for Reasonable People 21 (2d ed., Penguin Books 2006); Alain B. Burrese, Getting to 'Yes', 31 Mont. LAW. 36, 36 (2005); see also Stephen D. Easton, My Last Lecture: Unsolicited Advice for Future and Current Lawyers, 56 S.C. L. REV. 229, 236-37 (2004).

164 SCHNEIDER \& KUPFER, supra note 71, at 29. 
terests and priorities (separate from positions). ${ }^{165}$ Second, they will also understand their possible alternatives to reaching an agreement and set their BATNA - best alternative to a negotiated agreement. ${ }^{166}$ Finally, based on their BATNA, negotiators should then set their bottom line or reservation point, the point at which they will walk away from the deal. ${ }^{167}$ This preparation ensures that a negotiator will not make a bad deal, one that is actually worse than the alternatives. ${ }^{168}$

A negotiator also needs to set her goals. These goals should be specific, optimistic, and justifiable. ${ }^{169}$ When goals are specific, negotiators are more patient and will work harder to meet these goals. ${ }^{170}$ In order to set both optimistic and justifiable goals, the negotiator needs to prepare criteria and understand what would make any agreement fair. This research could include market rates, case law, business practices, or any other criteria that could be persuasive to the negotiation counterpart. With criteria in hand, a negotiator should set her goal at the optimistic end of the range of fair and comparable criteria. ${ }^{171}$ This will help set the first offer (which, when the negotiator is well-informed, can help set a favorable anchor). ${ }^{172} \mathrm{In}$ addition to anchoring the counterpart, setting the first offer high is crucial because that is the outer limit of what one will receive. (Rarely will a negotiator receive more than what she asks for!) And the goal, as well as the first ask, need to be seen as justifiable. This helps both the negotiator in terms of believing in one's own fairness, and helps sell this offer to the counterpart. ${ }^{173}$

The other component of assertiveness is the ability to persuade. All the knowledge in the world will not be helpful if the negotiator is unwilling or unable to ask. Moreover, how one asks for a goal or deliverable can determine how effective the negotiator can be. Talented negotiators will use framing, storytelling, and psychological tools in order to discover the most effective way to per-

165 See FISHER \& URY, supra note 77, at 103.

166 Id.

167 Id. at 104.

$168 \mathrm{Id}$. at 105.

169 See SHELL, supra note 163, at 28.

170 See Sidney Siegel \& Lawrence E. Fouraker, Bargaining and Group Decision MAKing: Experiments in Bilateral Monopoly 67 (1960); Jeffrey T. Polzer \& Margaret A. Neale, Constraints or Catalysts? Reexamining Goal Setting Within the Context of Negotiation, 8 Hum. Performance 3, 4 (1995).

171 Jennifer Gerarda Brown, The Role of Hope in Negotiation, 44 UCLA L. REV. 1661, 1676 (1997); Andrea Kupfer Schneider, Productive Ambition, in 1 The Negotiator's DesK REFERENCE, supra note 26, at 321, 322.

172 See Sally Blount White \& Margaret A. Neale, The Role of Negotiator Aspirations and Settlement Expectancies in Bargaining Outcomes, 57 Organizational Behav. \& Hum. DECision Processes 303, 306 (1994).

173 See Adam D. Galinsky et al., Disconnecting Outcomes and Evaluations: The Role of Negotiator Focus, 83 J. Personality \& Soc. Psychol. 1131, 1131 (2002); Russell Korobkin, Aspirations and Settlement, 88 CORNELL L. REV. 1, 3 (2002). 
suade the negotiation counterpart. ${ }^{174}$ Perhaps the counterpart will be persuaded by data, ${ }^{175}$ perhaps by a self-view of fairness, perhaps by the idea that this is a time-limited offer, ${ }^{176}$ or perhaps by the fact that the offer meets his own interests $^{177}$ (which one should assume is a minimum to any agreement). Each of these tools are valuable and effective negotiators will think carefully about which persuasion methods will work with which counterparts.

\section{Differences That Have Been Found}

As noted, assertiveness has been the skill most often studied in negotiation as it is the easiest to measure - studies examine the particular pieces of assertiveness - decisions as to whether to negotiate at all, where to set an opening offer, and the level of confidence shown by negotiators.

Many early studies on gender differences found that women are less likely to negotiate on their own behalf. This was tested both in lab studies and in salary negotiations and led to the idea that "women don't ask."178 (And this concept, that women don't ask, has now been used over time to explain the differences in women's salaries and positions across the economy.) ${ }^{179}$ Yet these studies have the constraints of competitive, one-shot interactions with limited

174 See Jonathan Herring, How to Argue: Powerfully, Persuasively, Positively 6, 32-35 (2012); Richard Maxwell \& Robert Dickman, The Elements of Persuasion 4 (2007); RobBEnNolt \& STERnlight, supra note 26, at 88, 325; Alice J. Lee \& Daniel R. Ames, "I Can't Pay More" Versus "It's Not Worth More": Divergent Effects of Constraint and Disparagement Rationales in Negotiations, 141 Organizational Behav. \& Hum. DECISION PROCESSES 16, 17-19 (2017) (studying graduate students enrolled in negotiation courses and finding that using constraint rationales (referring to one's own limited resources) may often yield benefits for buyers, in part because they are taken as signaling a buyer's limits while at the same time cultivating a positive image of the buyer).

175 See SHELL, supra note 163, at 51; Korobkin, supra note 173, at 32 (demonstrating that data, such as information about prices or outcome predictions, can anchor negotiators and be persuasive).

176 See Robert B. Cialdini, Influence: Science \& Practice 203 (5th ed. 2009) (discussing the impact of making the offer based on scarcity).

177 See FISHER \& URY, supra note 77, at 105.

178 Deborah A. Small et al., Who Goes to the Bargaining Table? The Influence of Gender and Framing on the Initiation of Negotiation, 93 J. PERSONALITY \& SOC. PSYCHOL. 600, 60103 (2007) (studying primarily students playing Boggle where each participant was offered \$3 for their results and asked, "is $\$ 3 \mathrm{OK}$ ?" If the participant initiated negotiation with the experimenter (i.e., asked for more money) then they received more money. If the participant complained-saying things like, "that sucks" or "how are these graded?" or even just asking "Three dollars? I thought the thing said 3-10." - and did not ask for more, they were not offered more money).

179 See generally Am. Ass'n of Univ. Women, The Simple Truth About the Gender Pay GAP 4 (2017); Kennedy \& Kray, supra note 3, at 3; Babcock et al., supra note 3, at 1; Pyramid: Women in S\&P 500 Companies, CATALYST (Aug. 22, 2017), http://www.catalyst.org/kn owledge/women-sp-500-companies [https://perma.cc/G8D7-B98B]; Statistical Overview of Women in the Workforce, CATALYST (Aug. 11, 2017), http://www.catalyst.org/knowledge/sta tistical-overview-women-workforce [https://perma.cc/R6KV-CT62]. 
time-frames and ability to gather information - arguably, the exact opposite of what negotiation situations would be in the workplace or on behalf of a client. These frameworks also completely eliminate the possibility of utilizing any other negotiation skill, a separate unrealistic assumption.

In more complex scenarios and studies, in fact, we can find data that shows that women do initiate negotiation at the same rate as men. Women will initiate negotiations when they are trained to do so. ${ }^{180}$ Women will negotiate when expected to negotiate - if this is part of their role on behalf of a client or company, ${ }^{181}$ when the job posting itself says that negotiation is expected, ${ }^{182}$ or when they have been told to negotiate. ${ }^{183}$ Women negotiate when they have information about the job. ${ }^{184}$ And in more recent studies, women will initiate negotiation at the same rates as men at work, ${ }^{185}$ so perhaps this assumption about not negotiating is also generational. Finally, the subject matter of the negotiation matters as well. Women will negotiate about "feminine" issues or interests more than men. ${ }^{186}$

180 Andrea Kupfer Schneider et al., Likeability v. Competence: The Impossible Choice Faced by Female Politicians, Attenuated by Lawyers, 17 Duke J. Gender L. \& POL'Y 363, 364-80 (2010) (advising that female lawyers should not deny or hide being a woman but should "be prepared to fight against stereotyping; and continue to create networks and mentoring at work to change the entire system"); see generally LINDA BABCOCK \& SARA Laschever, Ask For It: How Women Can Use the Power of Negotiation to Get What THEY REALLy WANT 38-56 (2008).

181 See generally Coren L. Apicella et al., No Gender Difference in Willingness to Compete When Competing Against Self, 107 Am. Econ. Rev.: PAPERS \& Proc. 136, 136-40 (2017) (studying over 1,000 online participants and discussing that women are more likely than men to shy away from competitive settings); Andreas Leibbrandt \& John A. List, Do Women Avoid Salary Negotiations? Evidence from a Large Scale Natural Field Experiment (NBER, Working Paper No. 18511, 2012) (studying over 2,000 random job applicants and finding that when not explicitly told that wages are negotiable, women are less likely than men to negotiate for a higher wage and are more likely to signal a willingness to work for a lower pay).

182 See Leibbrandt \& List, supra note 181, at 2; Small et al., supra note 178, at 601 (framing negotiation as "asking" versus "negotiat[ing]" reduced gender differences in the likelihood to negotiate).

183 See Leibbrandt \& List, supra note 181, at 2.

184 See id.; Julia Bear et al., Understanding the Gendered Path to Negotiation Experience: A Dual Components Model, Presentation at the International Association for Conflict Management Conference (July 9, 2018) (finding that reducing ambiguity reduces gender differences in negotiation); see generally Julia B. Bear \& Linda Babcock, Negotiating Femininity: Gender-Relevant Primes Improve Women's Economic Performance in Gender Role Incongruent Negotiations, 41 Psychol. Women Q. 163, 163 (2017) (studying male and female physicians, undergraduate students, and members of the community and discussing that "women, compared to men, underperform in masculine negotiations because these negotiations are incongruent with women's gender role").

185 See generally Benjamin Artz et al., Do Women Ask? 11-12 (Warwick Econ. Research Papers, Paper No. 1127, 2016).

186 See Julia B. Bear \& Linda Babcock, Negotiation Topic as a Moderator of Gender Differences in Negotiation, 23 PsYCHOL. SCI. 743, 743-44 (2012) (studying over 100 physicians 
As discussed above, effective negotiators need to set optimistic goals. Some studies have shown that women tend to set lower goals ${ }^{187}$ and, therefore, accept lower results in a negotiation. ${ }^{188}$ Setting appropriate goals is based on having appropriate information ${ }^{189}$ and women may not have the networks to gather enough information to set higher goals or may be more risk averse. ${ }^{190}$ More recent studies have shown that when the information is more transparent and available, this differential in goalsetting is mitigated. ${ }^{191}$

The amount of confidence that a negotiator has going into the negotiation is important in setting high goals beforehand, in having persistence during the negotiation, and in how one presents oneself. Studies show that men and women have significant differences in confidence levels ${ }^{192}$-leading to different kinds of concerns in negotiation. First, women historically are seen to have

and finding that men outperformed women when negotiating over masculine issues and women outperformed men when negotiating over feminine issues) [hereinafter Negotiation Topic]; Deborah Kolb \& Kathleen L. McGinn, Beyond Gender and Negotiation to Gendered Negotiations 5 (Harvard Bus. Sch., Working Paper No. 09-064, 2008).

187 Francesca Gino et al., Compared to Men, Women View Professional Advancement as Equally Attainable, But Less Desirable, 112 PNAS 12354, 12354 (2015) (“Across nine studies using diverse sample populations (executives in high-power positions, recent graduates of a top MBA program, undergraduate students, and online panels of working adults) and over 4,000 participants, we find that, compared to men, women have a higher number of life goals, place less importance on power-related goals, associate more negative outcomes (e.g., time constraints and tradeoffs) with high-power positions, perceive power as less desirable, and are less likely to take advantage of opportunities for professional advancement. Women view high-level positions as equally attainable as men do, but less desirable.").

188 Babcock et al., supra note 179. See generally Zachary Estes \& Sydney Felker, Confidence Mediates the Sex Difference in Mental Rotation Performance, 41 ARCHIVES SEXUAL BEHAV. 557, 557, 560, 563-64, 567 (2012) (studying undergraduate students and discussing differences in male and female confidence levels and its effect on negotiation results); John A. Rizzo \& Richard J. Zeckhauser, Pushing Incomes to Reference Points: Why Do Male Doctors Earn More?, 63 J. ECON. BEHAV. \& ORG. 514 (2007) (finding higher goal setting by male doctors explains the salary gap).

189 Meghan R. Busse et al., Repairing the Damage: The Effect of Price Knowledge and Gender on Auto Repair Price Quotes, 54 J. MARKETING RES. 75, 75 (2017) (“"[R]epair shops quote higher prices to callers who cite a higher benchmark price and that women are quoted higher prices than men when callers signal that they are uninformed about market prices. However, gender differences disappear when callers mention a benchmark price for the repair ... [ [R]epair shops are more likely to offer a price concession if asked to do so by a woman than if asked by a man.").

190 See generally Susan Fisk, Who's on Top? Gender Differences in Risk-Taking Produce Unequal Outcomes for High-Ability Women and Men, 8 Soc. Psychol. Q. 185 (2018) (discussing that women take fewer risks than men, which can produce gender inequality in outcomes).

191 See Negotiation Topic, supra note 186, at 744.

192 See Kay \& Shipman, supra note 149, at 104-05; Brooke De Lench, Home Team Advantage: The Critical Role of Mothers in Youth Sports 61 (2006); see generally Jana Cahliková et al., How Stress Affects Performance and Competitiveness Across Gender (Max Planck Inst. for Tax Law and Pub. Fin., Working Paper No. 1211-3298, 2017) (finding women are more impacted by stress in competitive situations). 
lower confidence in the marketplace, perhaps from lack of exposure or socialization or experience. ${ }^{193}$ Studies show that young women's confidence levels dip in high school before rebounding by adulthood. ${ }^{194}$ This dip in confidence, which tracks through college, also raises concerns on those historic studies done on college students. While these negotiation studies may measure differences in college-aged men and women accurately, these studies have been used to draw far larger conclusions about negotiation differences for men and women of all ages. ${ }^{195}$

Men typically measure higher in confidence levels, ${ }^{196}$ even tending toward overconfidence, a very common negotiation mistake. ${ }^{197}$ When negotiators are too confident about their position, they can escalate the negotiation or create hostility with the other side. ${ }^{198}$ Alternatively, overconfident negotiators can miss opportunities to work with the other side. Or these negotiators can also refuse to admit past mistakes, and lack of knowledge, or be unwilling to listen. ${ }^{199}$ All of these faults in negotiation are reviewed extensively in negotiation literature as significant road blocks. ${ }^{200}$ And it would appear from the studies on confidence that men are far more likely to fall into this trap. ${ }^{201}$

193 See Christopher F. Karpowitz \& Tali Mendelberg, The Silent Sex 53 (2014); Kay \& SHIPMAN, supra note 149, at 104.

194 See Claire Shipman et al., How Puberty Kills Girls' Confidence, AtLantic (Sept. 20, 2018), https://www.theatlantic.com/family/archive/2018/09/puberty-girls-confidence/563804 [https://perma.cc/UAP6-YFMT]; see generally Ravenna Helson \& Gerladine Moane, Personality Change in Women From College to Midlife, 53 J. Personality And Soc. Psychol. 176 (1987). Numerous studies over time show that women's confidence increases with age. Abigail J. Stewart et al., Middle Aging in Women: Patterns of Personality Change from the 30 s to the 50s, 8 J. AdULt DeV. 23 (2001).

195 See, e.g., KAY \& SHIPMAN, supra note 149, at 104-05; DE LENCH, supra note 192, at 61.

196 Sandra R. Farber \& Monica Rickenburg, Under-Confident Women and Over-Confident Men: Gender and Sense of Competence in a Simulated Negotiation, 11 YALE J.L. \& FEMINISM 271, 283 (1999).

197 William H. Peace, The Hard Work of Being a Soft Manager, Harv. Bus. Rev. (Dec. 2001), https://hbr.org/2001/12/the-hard-work-of-being-a-soft-manager [https://perma.cc/4R

HP-XWMX] (explaining effective management requires vulnerability); see generally Carmen Sanchez \& David Dunning, Overconfidence Among Beginners: Is a Little Learning a Dangerous Thing?, 114 J. Personality \& Soc. Psychol. 10 (2018).

198 Therese Huston, Men Can Be So Hormonal, N.Y. Times (June 24, 2017), https://www. nytimes.com/2017/06/24/opinion/sunday/men-testosterone-hormones.html [https:/perma.cc/ TG5R-K4V3] (finding that men are "more likely to overestimate how well they'll perform compared with their peers.").

199 Joseph T. Hallinan, Why We Make Mistakes: How We Look Without Seeing, Forget Things in Seconds, and Are All Pretty Sure We Are Way Above Average 8-9 (2009).

200 Id. at $135-37$ (explaining that men are far more overconfident).

201 Chamorro-Premuzic, supra note 150 ("[A]rrogance and overconfidence are inversely related to leadership talent - the ability to build and maintain high-performing teams, and to inspire followers to set aside their selfish agendas in order to work for the common interest of the group. Indeed, whether in sports, politics or business, the best leaders are usually 
One of the reasons women traditionally do not assert themselves in negotiation is the fear of backlash - the fear of not being liked - and therefore lose out on the substantive part of the negotiation. This has been well documented in early employment discrimination cases, ${ }^{202}$ in politics, ${ }^{203}$ and in lab studies ${ }^{204}$ assessing how women are perceived. So, in fact, if one paid attention to these studies, one might question any advice that counsels women to be assertive. ${ }^{205}$ Many negotiation articles have focused on advice for women in terms of mitigating or minimizing any potential backlash. ${ }^{206}$ Yet in more recent studies (and further examination of earlier studies) two key discoveries were found. ${ }^{207}$ First, language actually mattered. ${ }^{208}$ When the language used to express dismay over the offer was firm, women faced no backlash. ${ }^{209}$ Only when the language was far more hostile did women face backlash. ${ }^{210}$ And, so, a blanket rule that wom-

humble - and whether through nature or nurture, humility is a much more common feature in women than men.").

202 Victoria L. Brescoll, Who Takes the Floor and Why: Gender, Power, and Volubility in Organizations, 56 ADMIN. SCI. Q. 622, 635-37 (2011) (finding that women in power do not talk as much as men in power, correctly perceiving there might be backlash); Schneider et al., supra note 180, at 370 (2010) (discussing the Ann Hopkins case); see also Michelle A. Travis, Disabling the Gender Pay Gap: Lessons from the Social Model of Disability, 91 DENV. U. L. REV. 893, 898-99 (2014).

203 See generally Ann C. McGinley, Hillary Clinton, Sarah Palin, and Michelle Obama: Performing Gender, Race, and Class on the Campaign Trail, 86 DENV. U. L. REV. 709, 71419 (2009); Andrea Kupfer Schneider et al., Leadership and Lawyering Lessons From the 2008 Elections, 30 Hamline J. PuB. L. \& Pol'y 581 (2009).

204 See BABCOCK \& LASCHEVER, supra note 3, at 1-3; Emily T. Amanatullah \& Catherine H. Tinsley, Ask and Ye Shall Receive? How Gender and Status Moderate Negotiation Success, 6 Negot. \& Conflict Mgmt. Res. 253, 253 (2013) (extending research on the backlash women receive for being assertive in negotiations and finding that "women also incur financial penalties for initiating negotiations" in a study of undergraduate students); Lisa A. Barron, Ask and You Shall Receive? Gender Differences in Negotiators' Beliefs About Requests for a Higher Salary, 56 Hum. REL. 635, 651 (2003) (discussing that the potential for social backlash can inhibit women from taking assertive actions); Rebecca L. Schaumberg \& Francis J. Flynn, Self-Reliance: A Gender Perspective on its Relationship to Communality and Leadership Evaluations, 60 ACAD. MGMT. J. 1859, 1864-65 (2017) (finding that perceiving women leaders as self-reliant gave them an advantage over men).

205 Olga Khazan, Women Know When Negotiating Isn't Worth It, Atlantic (Jan. 6, 2017), https://www.theatlantic.com/business/archive/2017/01/women-negotiating/512174/ [https://p erma.cc/X5AF-A4NG].

206 See, e.g., Catherine H. Tinsley et al., Women at the Bargaining Table: Pitfalls and Prospects, 25 NeGOT. J. 233, 237-38 (2009).

207 Nazli Bhatia et al., Assertiveness Versus Aggression in Negotiation, Presentation at the 30th Annual Conference of the International Association for Conflict Management (July 11, 2017).

208 See id. at 27.

209 See id. at 26.

210 See id. at 19. 
en should not assert for fear of being unlikeable is far too broad. ${ }^{211}$ Second, when the language used to express dismay was hostile, it was in fact men that faced more of a backlash. ${ }^{212}$ The broader lesson should be that all negotiators must consider the language they use in making demands and counteroffers and that all negotiators can avoid backlash by moderating the framing of their firm dismay.

\section{Future Research Directions}

As assertiveness has been the most studied negotiation skill, we benefit from significant research. However, these studies are often in one-shot and competitive interactions not matching the actual negotiations where parties will deal with each other repeatedly. ${ }^{213}$ At the same time, it is important to note that these studies have, in some ways, become self-fulfilling prophecies. If one only measures assertiveness by a direct ask (a more masculine form of communication) versus objecting about the fairness of the offer (a more indirect and feminine form of communication) one can find clear differences-yet it is unclear that the latter indirect form does not work over time to change the situation. Similarly, other pieces of assertiveness-such as framing or utilizing different tools of persuasion - have not yet been studied since these would require far more detailed experimental methods. Most studies on assertiveness assume a one-time interaction with a competitive binary goal and limited information. ${ }^{214}$ These study frameworks are, therefore, limited by their own parameters to only find certain parts of what makes a negotiator assertive. (For example, persistence where one negotiates over time to accomplish a goal, cannot be measured this way.) In particular for these studies, it will be important to note the setup of the study and on what group the study is being performed. More research using more sophisticated types of negotiations would be beneficial. Moreover, conclusions from research on assertiveness has been misused to justify lack of equality and ignore structural and socialized barriers that women face in the workplace. ${ }^{215}$ Being cognizant of the research's impact should help researchers

211 Shira Mor et al., Gender/Professional Identity Integration Promotes Women's Negotiation Performance via Reduced Social Backlash Concerns (Sept. 2015) (unpublished manuscript), https://www.researchgate.net/publication/281836018_GenderProfessional_Identity Integration_Promotes_Women's_Negotiation_Performance_via_Reduced_Social_Backlash _Concerns [https://perma.cc/V5GW-FVY6]. See generally Melissa J. Williams \& Larissa Z. Tiedens, The Subtle Suspension of Backlash: A Meta-Analysis of Penalties for Women's Implicit and Explicit Dominance Behavior, 142 Psychol. Bull. 165 (2016) (finding that when dominance was expressed through direct demands, there was a negative effect on the woman's likeability).

212 Bhatia et al., supra note 207, at 25.

213 See id. at 12.

214 See, e.g., Small et al., supra note 178, at 603; see also Bear \& Babcock, supra note 184, at 166; Bear et al., supra note 184.

215 Yun Kim et al., supra note 4, at 974. 
more narrowly circumscribe what lessons can be learned from which studies. ${ }^{216}$ As one who has, for example, used the term "likeable" in describing women's negotiation behavior (while not worrying about that for men), does this perpetuate the bias and unequal measures of successful negotiation behaviors? We can do better.

\section{CONCLUSION}

There are (at least) three things that are wrong with research on women and negotiation. The first is that we study gender differences in negotiation and assume that these differences - as opposed to any other professional, cultural, age, or experiential difference - are determinative of differences in negotiation behavior. These stereotypes may or may not apply to any one of us in particular. Our behaviors in negotiation likely fall along a range from "masculine" to "feminine" that may or may not actually match our gender. If we examined negotiation behaviors using other lens-professional training, experience, family and culture, geography, or birth order-just to name a few, we would likely find similar ranges of behaviors. In other words, none of these studies show that gender is determinative of any single individual's skill sets. (And this is yet another whole area calling out for more research.)

A second lesson that should resonate through this article is that assertiveness is only one skill — out of at least five - in negotiation that makes one effective. We have studied one important skill, but it is only one of at least five, and there is no reason to think that results about this skill extend to the other four. Indeed, available research suggests the opposite. Since it has been relatively easy to study in the lab and in one-shot negotiations, that is what we study. (We only study the hammer and assume one swing.) And, as women have been historically socialized against being assertive (with resulting backlash if the appropriate boundaries are crossed), it is not surprising that women are then seen as less effective in those types of studies. And more recent studies even show the limit of assuming that women lack assertiveness. Nonetheless, if it is the only skill one studies, it appears to be the only one that counts. And this ignores the other skills-particularly social intuition, empathy, and ethicality-in which women appear to excel.

This leads to the third lesson-focusing solely on assertiveness is not only doing a disservice to women, it harms any negotiator who assumes that modulating their level of assertiveness is the only thing it takes in order to be effective. Both business and negotiation literature are consistent in noting that these other skills discussed in the article are exactly the types of skills the best leaders will possess. The studies in each of these skillsets should help us determine

216 See generally Julia B. Bear \& Peter Glick, Breadwinner Bonus and Caregiver Penalty in Workplace Rewards for Men and Women, 8 Soc. Psychol. \& Personality ScI. 780 (2017) (giving women specific tips on how to frame their requests for higher salary). 
[Vol. 19:3

what skills we have and what we are lacking. Since empirical work often focuses on micro-skills - ability to read emotion from the eyes, how to listen more carefully, when to make an offer-these studies can highlight exactly what we need to consider in order to change behavior to be more effective in negotiation. Further research into all of these skills in the context of negotiation is needed.

Only when we fix the research-only when we study more than the hammer-can we really trust that the lessons we draw are accurate and appropriate fixes for each of us individually. 